\title{
Combined effects of ozone and drought stress on the emission of biogenic volatile organic compounds from Quercus robur $\mathrm{L}$.
}

\author{
Arianna Peron ${ }^{1}$, Lisa Kaser ${ }^{1}$, Anne Charlott Fitzky ${ }^{2}$, Martin Graus ${ }^{1}$, Heidi Halbwirth ${ }^{3}$, Jürgen Greiner ${ }^{3}$, \\ Georg Wohlfahrt ${ }^{4}$, Boris Rewald ${ }^{2}$, Hans Sandén ${ }^{2}$, and Thomas Karl ${ }^{1}$ \\ ${ }^{1}$ Department of Atmospheric and Cryospheric Sciences, University of Innsbruck, 6020 Innsbruck, Austria \\ ${ }^{2}$ Department of Forest and Soil Sciences, Forest Ecology, University of Natural Resources and Life Sciences \\ Vienna (BOKU), 1190 Vienna, Austria \\ ${ }^{3}$ Institut für Verfahrenstechnik, Umwelttechnik und Technische Biowissenschaften, Technische \\ Universität Wien, 1060 Vienna, Austria \\ ${ }^{4}$ Department of Ecology, University of Innsbruck, 6020 Innsbruck, Austria
}

Correspondence: Thomas Karl (thomas.karl@uibk.ac.at)

Received: 7 July 2020 - Discussion started: 6 August 2020

Revised: 14 October 2020 - Accepted: 21 November 2020 - Published: 22 January 2021

\begin{abstract}
Drought events are expected to become more frequent with climate change. To predict the effect of plant emissions on air quality and potential feedback effects on climate, the study of biogenic volatile organic compound emissions under stress is of great importance. Trees can often be subject to a combination of abiotic stresses, for example due to drought or ozone. Even though there is a large body of knowledge on individual stress factors, the effects of combined stressors are not much explored. This study aimed to investigate changes of biogenic volatile organic compound emissions and physiological parameters in Quercus robur L. during moderate to severe drought in combination with ozone stress. Results show that isoprene emissions decreased while monoterpene and sesquiterpene emissions increased during the progression of drought. We exposed plants with daily ozone concentrations of $100 \mathrm{ppb}$ for $1 \mathrm{~h}$ for $7 \mathrm{~d}$, which resulted in faster stomatal closure (e.g., a mean value of $-31.3 \%$ at an average stem water potential of $-1 \mathrm{MPa}$ ), partially mitigating drought stress effects. Evidence of this was found in enhanced green leaf volatiles in trees without ozone fumigation, indicating cellular damage. In addition we observed an enhancement in $\left(\mathrm{C}_{8} \mathrm{H}_{8} \mathrm{O}_{3}\right) \mathrm{H}^{+}$ emissions likely corresponding to methyl-salicylate in trees with ozone treatment. Individual plant stress factors are not
\end{abstract}

necessarily additive, and atmospheric models should implement stress feedback loops to study regional-scale effects.

\section{Introduction}

Plants, in both natural and managed ecosystems, release biogenic volatile organic compounds (BVOCs), covering over 30000 known compounds (Peñuelas and Llusiá, 2004). These molecules have different physical and chemical characteristics and they differ in their metabolic origins in plants (Peñuelas and Llusiá, 2001; Laothawornkitkul et al., 2009; Maffei, 2010). An important subset of BVOCs are isoprenoids, such as isoprene (IS), monoterpenes (MTs), and sesquiterpenes (SQTs). The estimated global annual flux of IS ranges from 440 to $600 \mathrm{Tg} \mathrm{C} \mathrm{yr}^{-1}$ (Guenther et al., 2012). These values correspond to $2 \%$ of the photosynthetically fixed carbon (Lal, 1999) and comprise a significant part of the total annual emission of BVOCs on a global scale of $1150 \mathrm{Tg}$ C (Guenther et al., 1995).

The emission of BVOCs is strongly influenced by external factors (Peñuelas and Llusiá, 2003; Niinemets et al., 2004; Fitzky et al., 2019). BVOCs are thought to play a role in protecting vegetation from abiotic (Peñuelas and MunnéBosch, 2005; Velikova et al., 2005) and biotic stress (Berg 
et al., 2013; Amin et al., 2012, 2013) and to act as a system for plant-plant and plant-animal communication (Baldwin et al., 2006; Filella et al., 2013).

Future climate scenarios with expected temperature increases between 1.8 and $4{ }^{\circ} \mathrm{C}$ (IPCC, 2007) suggest an additional enhancement of global BVOC emissions between $30 \%$ and $45 \%$ (Peñuelas and Llusiá, 2003). An enhancement of abiotic stress events, due to an indirect effect of a temperature increase (e.g., via ozone or drought episodes) can also alter BVOC emissions (EEA, 2017; Müller et al., 2008; Loreto and Schnitzler, 2010; Dai, 2013; Unger et al., 2013; Sindelarova et al., 2014). Drought stress can change the composition of BVOCs emitted by plants, depending on the nature of stress (Niinemets, 2010). Pegoraro et al. (2004) and Beckett et al. (2012) have shown that the gradual suppression of physiological processes of plants in response to drought stress initially leads to an increase in isoprene emissions, followed by a tapering off of isoprene emissions. In the initial phase of stress, the plant responds via a reduction of stomatal conductance, leading to reduced transpiration rate; this results in an increase in temperature at the leaf level and a decrease in carbon assimilation (Siddique et al., 2000). Although emissions tend to increase initially due to reserves of reduced carbon present in the plant, isoprene emissions decrease under severe drought stress (Tingey, 1981; Pegoraro et al., 2004).

Besides increasing temperature and more severe droughts, future climate scenarios predict increasing ozone concentrations (Bowen, 1926; Kangasjärvi et al., 1994; Hollaway et al., 2012). Long-term elevated tropospheric ozone concentration affects BVOC emissions (Peñuelas et al., 1999) and induces alterations in photosynthetic performance, increasing the production of reactive oxygen species (ROSs) (Cotrozzi et al., 2017; Jolivet et al., 2016).

Ground-level $\mathrm{O}_{3}$ concentrations in the pre-industrial period were around $10 \mathrm{ppb}$ in Europe (Volz and Kley, 1988; Royal Society, 2008). For the period 2000-2014, the average ozone concentrations during the growing season (April to September) in European forests were $36.2 \mathrm{ppb}$, ranging from 14.5 to $70.1 \mathrm{ppb}$ (Schaub et al., 2018). Instances of severe ozone pollution were recorded during the heat wave of summer 2003 in Europe, with peaks > 100 ppbv in UK (Lee et al., 2006).

Among plants, trees are the dominant source of BVOC emissions (Guenther et al., 1995), and they are not often subject to only one stress but to a combination of stresses (Fitzky et al., 2019). For example, drought and ozone stresses can often occur in parallel. The combinations of these stress factors are difficult to understand because ozone and drought stress individually lead to similar symptoms, such as cell dehydration, early senescence, and cell necrosis (Chaves et al., 2003). A typical class of compounds emitted by plants in a situation of stress is green leaf volatiles (GLVs). Their emissions are indicators for damage of cellular membranes (Hatanaka, 1993; Croft et al., 1993). Other BVOCs are the product of metabolic processes in plants such as transcription and enzymatic activity which are induced by various stimuli, for example ozone (Betz et al., 2009). An example of such a BVOC is methyl salicylate (MeSa), produced by the shikimate pathway (Kessler and Balwin, 2001), which fixes $20 \%$ of the carbon obtained from photosynthesis (Bentley and Haslam, 2008; Herrmann and Weaver, 1999).

Few studies have analyzed the effects of plant emissions from a combination of drought and ozone stress (Vitale et al., 2008; Yuan et al., 2016). Studying Quercus ilex, Vitale et al. (2008) reported that drought stress leads to stomatal closure, therefore reducing stress by ozone as it is restricted to enter the leaf. They did not report effects of ozone when going from a well-watered situation to severe stress. Yuan et al. (2016) found that drought increased isoprene emissions in a hybrid poplar deltoid species but that isoprene emissions decreased under moderate drought stress combined with long-term ozone fumigation. In their case, Yuan et al. (2016) analyzed the emissions under a situation of moderate drought stress.

Here we are also interested in the situation of severe stress that could occur in the future due to climate change, combined with model projections of elevated ozone concentrations (>100 ppb).

Pollastrini et al. (2014) consider a change in sensitivity of the plants to ozone (different poplar clones) under severe drought conditions. In their case, ozone and drought produced a synergistic effect for $\mathrm{CO}_{2}$ exchange and chlorophyll fluorescence when applied together. Wittig et al. (2007) found a dependency on ozone effects under different levels of drought stress. In fact, Wittig et al. (2007) report a dependency of the damage in the photosynthetic apparatus depending on the cumulative ozone flux into the leaf, thus in relation to stomatal conductance.

In this work, our hypothesis was that ozone and drought stresses in plants are not necessarily additive and that the plant's response to drought and ozone exposure can result in an alteration of characteristic BVOC emission strengths. Changing BVOC emissions have an important impact on climate through atmospheric chemistry (Claeys et al., 2004; Paulot et al., 2009; Hallquist et al., 2009). The presence of BVOCs in the atmosphere contributes to the formation of tropospheric ozone and growth of secondary organic aerosol (SOA) and radicals (Griffin et al., 1999; Orlando et al., 2000; Atkinson and Arey, 2003).

As a model plant we chose Quercus robur L., a widely distributed isoprene-emitting oak species in Europe (Barstow and Khela, 2017), considered not at risk of extinction (Barstow and Khela, 2017).

In the future, this species may become more threatened (Barstow and Khela, 2017), triggering a migration from the current climate range to a zone more representative of the north and east of Europe (EFDAC, 2015). Climate change could also expose $Q$. robur to greater environmental stress from drought (Jonsson, 2012). Understanding how BVOC 
emissions respond to climate change is therefore essential to understand what direct or indirect actions they can have on the biosphere-atmosphere-climate system and to develop strategies necessary to mitigate the effects of climate change itself (Kulmala et al., 2004; Yuan et al., 2009).

\section{Materials and methods}

\subsection{Plant species and stress treatments}

Q. robur is a broadleaf tree species widely distributed in Europe growing in mixed and deciduous forest ranging from sea level up to $1200 \mathrm{~m}$ a.s.l. (Ülker et al., 2018). According to Ellenberg (1988), the defensive actions of $Q$. robur against drought stress are caused by fast regulation of transpiration rates and stomatal conductance and a low susceptibility of water embolism in the xylem (Van Hees, 1997).

Fourteen 2-year-old $Q$. robur seedlings were planted in $7 \mathrm{~L}$ pots in March 2019. The substrate consisted of one-thirds of soil used by the city gardeners for city trees in Vienna and two-thirds of quartz sand to improve drainage. The plants were fertilized once after planting (universal fertilizer Novatec, Compo, Münster, Germany) and from thereon kept well-watered in a greenhouse at near-ambient light $(80 \%$ to $90 \%$ of photosynthetically active radiation) (Lak et al., 2020). The trees were moved from a greenhouse in Tulln into another close-by greenhouse in Vienna 2 weeks prior to the experiments. Dust was removed from the leaves by showering the trees before starting the drought stress.

For the biochemical reference assays, 8 trees of the initial 14 were used: four well-watered plants $(C)$ and four wellwatered plants receiving $100 \mathrm{ppb}$ ozone for $1 \mathrm{~h}$ one time (OS) inside the enclosures. The remainder (six plants) were used for BVOC emission measurements, $\mathrm{CO}_{2}$ and $\mathrm{H}_{2} \mathrm{O}$ gas exchange measurements, and biochemical assays. Hereby, we were left with three replicates under drought stress (DS) and three replicates exposed to drought stress and ozone $(\mathrm{DS} \times \mathrm{OS})$. The drought stress was initiated for all six plants $10 \mathrm{~d}$ before the VOC measurements started and was maintained by keeping the soil water content at 4 vol \%-5 vol \% using a soil moisture probe (FieldScout TDR100, $20 \mathrm{~cm}$ probe depth, Spectrum 105 Technologies, UK), whereas $100 \%$ field capacity was 13.4 vol \%. With the start of VOC measurements, we stopped watering the previously droughtstressed trees to further increase drought stress.

The plants were moved from the greenhouse to an indoor climate chamber (Fitotron Weiss Gallenkamp, UK) $24 \mathrm{~h}$ before the experiment started. Thereafter trees were kept in the climate chamber for the remainder of the experiment and were only placed into the branch enclosures during the gas exchange measurements. The branch enclosures were situated next to the climate chamber in a climatized laboratory exhibiting the same environmental conditions as in the climate chamber. The climate conditions during the first day of experiment were kept at $25^{\circ} \mathrm{C}, \sim 60 \%$ relative humidity $(\mathrm{RH})$, and $\sim 1000 \mu \mathrm{mol} \mathrm{m} \mathrm{s}^{-1}$ photosynthetically active radiation (PAR) at canopy top, to adapt to constant air temperature. To continuously increase the drought stress, the plants were not watered and the humidity in the climate chamber was decreased to $40 \% \mathrm{RH}$ and temperature was increased to $30^{\circ} \mathrm{C}$ after the first day. The same temperature conditions were also present in the climatized laboratory, where the plants were placed in the enclosures at an $\mathrm{RH}$ of $32 \%$ and $30{ }^{\circ} \mathrm{C}$. Overall light conditions remained constant during the day, with lights off during the night.

To study the effect of ozone exposure of trees during increasing drought, the six trees mentioned above were separated into two groups: three trees were drought stressed and fumigated with $100 \mathrm{ppb} \mathrm{O}_{3}(\mathrm{DS} \times \mathrm{OS})$ inside the enclosure for $1 \mathrm{~h}$ each day after the daily measurement of BVOCs. The other three trees were drought stressed but not fumigated with ozone (DS).

At the end of the experiment leaves were harvested for leaf area and enzyme analysis. Values of the enzymatic activity of $\mathrm{C}$ and OS were compared to DS and DS $\times$ OS to investigate the effect of ozone fumigation.

\subsection{Measurement of leaf gas exchange and BVOC fluxes}

Throughout the increasing drought stress, tree leaf gas exchange $\left(\mathrm{CO}_{2}\right.$ and $\left.\mathrm{H}_{2} \mathrm{O}\right)$ and $\mathrm{BVOC}$ emissions were measured for two sets, DS and DS $\times$ OS, over a $7 \mathrm{~d}$ period, one in the morning and one in the afternoon alternating daily. The plants were taken out of the climate chamber and kept inside the custom-made plant enclosures (Fig. 1; TC-400, Vienna Scientific Instruments $\mathrm{GmbH}$, Alland, Austria) for 2$3 \mathrm{~h}$ each day in order to measure their $\mathrm{CO}_{2}$ and $\mathrm{H}_{2} \mathrm{O}$ exchange along with key physiological parameters (soil moisture and stem water potential). After the measurements inside the enclosures, the plants were moved back to the climate chamber until the next measurement session. The plant enclosures covered most of the plant material excluding a few leaves (about seven on each tree) to allow determination of stem water potential (SWP). Each day, one leaf was wrapped in aluminum foil and placed in a plastic bag for equilibrating to SWP (Williams and Araujo, 2002). After darkening for $30 \mathrm{~min}$ the leaf was cut off and SWP was measured by using a Scholander pressure bomb (Soilmoisture Equipment Corp., Goleta, CA, USA).

The four custom-made plant enclosures (12 L) were lined with PTFE and sealed on top with $55 \times 60 \mathrm{~cm}$ PET bags. The plant enclosures were continuously flushed with $10 \mathrm{~L} \mathrm{~min}^{-1}$ of ambient outside air that was previously passed through a cold trap to remove water and an activated carbon filter $\left(360 \mathrm{~m}^{3} \mathrm{~h}^{-1}\right.$, Prima Klima Trading, Radnice, $\left.\mathrm{CZ}\right)$ to remove VOCs and $\mathrm{O}_{3}$. This resulted in $32 \% \mathrm{RH}$ air and $\sim 370 \mathrm{ppm}$ $\mathrm{CO}_{2}$ entering the enclosures (experimental conditions in Appendix A, Table A1). The flow rate of $10 \mathrm{~L} \mathrm{~min}^{-1}$, tested dur- 


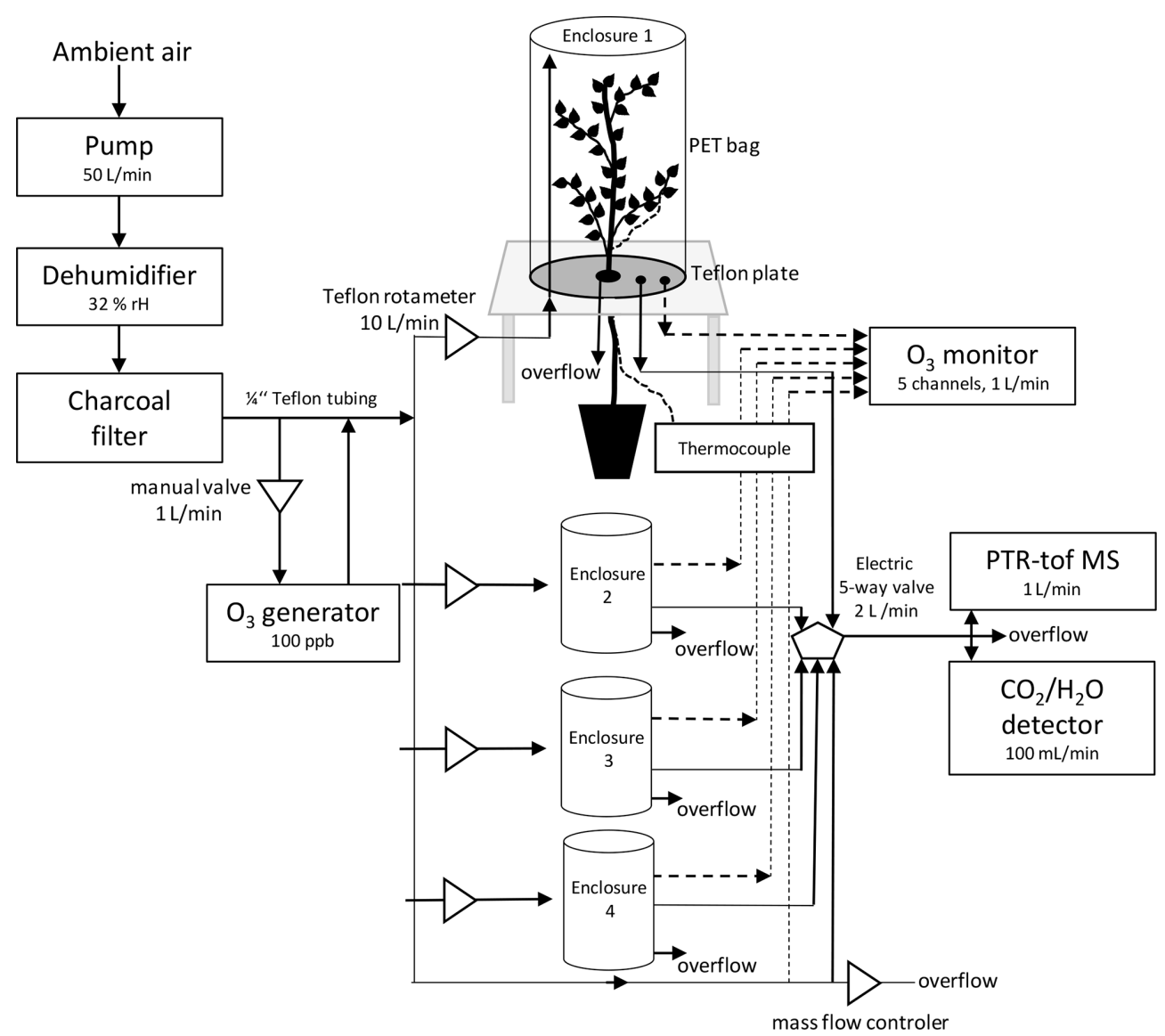

Figure 1. Scheme of a custom-made plant enclosure and set-up of the experiment. In brief, the chambers consisted of a PTFE-covered bottom plate with an opening mechanism to insert and seal the plant stem using PTFE plugs; furthermore, the bottom plate featured three inand outlets for gas sampling and ozone exposure; the inlet was raised above the bottom plate to allow for air mixing. The upper part of the chamber consisted of a transparent, $12 \mathrm{~L}$ PET bag, holding most of the tree crown. The bags were tightly sealed towards the bottom plate.

ing the experiment set-up prior to the actual experiments, assured that no condensation of water occurred in the tubing and enclosures as well as resulted in a slight overpressure preventing the entry of room air into the enclosures. Three of the enclosures were used to measure the air-gas exchange of the plants and the fourth enclosure was kept empty as a reference to allow continuous monitoring of the air entering the enclosures. Trees inside the enclosure were LED-irradiated with a mean PAR value of $1374 \mu \mathrm{mol} \mathrm{m}^{-2} \mathrm{~s}^{-1}$ at canopy top (Eckel Electronics, Trofaiach, Austria) during daytime when the exchange measurements were performed. During night, trees were kept in the dark. Leaf temperature was monitored in each enclosure by placing a calibrated $\left( \pm 0.1^{\circ} \mathrm{C}\right)$ thermocouple (type $k$, PTFE IEC wire; Labfacility Ltd, Bognor Regis, West Sussex, UK) on the abaxial side of a mature midcanopy leaf.

An automated valve system allowed the consecutive analysis of air exiting each enclosure for $5 \mathrm{~min}$ each, leading to a 20 min cycle through the four enclosures. Before inserting the three trees into the enclosures, background measurements of the empty enclosures were carried out. After inserting each plant into one enclosure, the plant was allowed to acclimatize for approximately $2 \mathrm{~h}$, and the following 40-60 $\mathrm{min}$ of data were analyzed to determine plant $\mathrm{CO}_{2}$ assimilation, transpiration, and $\mathrm{BVOC}$ emissions rates. After the measurements, the trees of DS $\times$ OS were fumigated for $1 \mathrm{~h}$ with $100 \mathrm{ppb}$ of ozone each day.

$\mathrm{CO}_{2}$ and $\mathrm{H}_{2} \mathrm{O}$ mixing ratios in the air leaving the enclosures were measured using a CIRAS-3 SC PP system (Amesbury, MA, USA), which was factory calibrated 3 months before the measurement campaign. Ozone measurements before and after the enclosures were conducted continuously in all enclosures with an ozone monitor (six-channel ozone monitor BMT 932, BMT Messtechnik, Berlin, Germany). BVOC measurements were made using a protontransfer-reaction time-of-flight mass spectrometer (PTR-TofMS, PTR-TOF 6000X2, IONICON Analytik GmbH, Innsbruck, Austria; Graus et al., 2010) operated at $350 \mathrm{~V}$ drift voltage, ion funnel settings of $1 \mathrm{MHz}$ and $35 \mathrm{~V}$ amplitude as well as $35 \mathrm{VDC}$, and $2.5 \mathrm{mbar}$ drift pressure. These settings are comparable to an $E / N$ of $100 \mathrm{Td}$ in a PTR-TOF 8000 with no ion funnel (Markus Müller, IONICON Analytic 
$\mathrm{GmbH}$, personal communication 2019). The drift tube temperature was $100^{\circ} \mathrm{C}$. Full PTR-Tof-MS mass spectra were collected with a time resolution of $1 \mathrm{~s}$ and up to a mass-tocharge ratio $\mathrm{m} / \mathrm{z}$ of $547 \mathrm{amu}$. The instrument background was characterized daily during calibrations and in the third empty enclosure that was flushed with background air. Backgrounds were measured every $20 \mathrm{~min}$ for $5 \mathrm{~min}$. Humiditydependent dynamic calibrations of VOCs using a standard gas mixture (Apel Riemer Environmental Inc., Broomfield, CO, USA), containing 15 compounds (Table A2) with different functionality distributed over a mass range of 33$137 \mathrm{amu}$, were performed daily. Daily measured sensitivities based on compounds in a calibration standard varied on the order of $8 \%-20 \%$ depending on the compound. This lies within the combined calibration uncertainties of the gas standard and dilution setup using two flow controllers. Whenever a compound was not contained in the calibration standard, we applied a compound-specific sensitivity using procedures described by Cappellin et al. (2012). The PTR-Tof-MS data were analyzed using the PTR-TOF Data Analyzer v4 software (Müller et al., 2013) and customized MATLAB scripts to obtain volume mixing ratios in the enclosures. The PTR-Tof-MS instrument has a high enough mass resolution to obtain isobaric formulas, minimizing potential interferences compared to quadrupole mass spectrometers. Strictly speaking measurements represented here are characterized by the isobaric formulas. The instrument was run in $\mathrm{H}_{3} \mathrm{O}^{+}$mode, detecting isoprene (IS), at $m / z 69.070\left[\left(\mathrm{C}_{5} \mathrm{H}_{8}\right) \mathrm{H}^{+}\right]$, the sum of monoterpenes (MTs) at $m / z 137.133\left[\left(\mathrm{C}_{10} \mathrm{H}_{16}\right) \mathrm{H}^{+}\right]$, the major fragment at $\mathrm{m} / z$ $81.070\left[\left(\mathrm{C}_{6} \mathrm{H}_{8}\right) \mathrm{H}^{+}\right]$, and the sum of sesquiterpenes (SQTs) at $m / z 205.195\left[\left(\mathrm{C}_{15} \mathrm{H}_{24}\right) \mathrm{H}^{+}\right]$and $m / z 149\left[\left(\mathrm{C}_{11} \mathrm{H}_{16}\right) \mathrm{H}^{+}\right]$. The identity of isoprene and monoterpenes was additionally confirmed by gas chromatography-mass spectrometry (GC-MS) measurements. The sum of GLVs presented in this study was monitored on $\mathrm{m} / \mathrm{z}$ of $83.085,85.101$, 99.080, 101.096, and 143.107, representing 2-hexenal and 3-hexenal $\left[\left(\mathrm{C}_{6} \mathrm{H}_{10} \mathrm{O}\right) \mathrm{H}^{+}\right]$, 3-hexenol $\left[\left(\mathrm{C}_{6} \mathrm{H}_{12} \mathrm{O}\right) \mathrm{H}^{+}\right]$, 1hexanol $\left[\left(\mathrm{C}_{6} \mathrm{H}_{14} \mathrm{O}\right) \mathrm{H}^{+}\right]$, 3-hexenol $\left[\left(\mathrm{C}_{6} \mathrm{H}_{12} \mathrm{O}\right) \mathrm{H}^{+}\right]$, and hexenyl acetate $\left[\left(\mathrm{C}_{8} \mathrm{H}_{14} \mathrm{O}_{2}\right) \mathrm{H}^{+}\right]$, respectively (Beauchamp et al., 2005; Giacomuzzi et al., 2016; Portillo-Estrada et al., 2017). The correspondence of these ions to GLV has been demonstrated by previous studies (e.g., Fall et al., 1999; Karl et al., 2001, 2005). Shikimate BVOCs were tentatively assigned to benzene as $m / z 79.054\left[\left(\mathrm{C}_{6} \mathrm{H}_{7}\right) \mathrm{H}^{+}\right]$, phenol as $m / z 95.050\left[\left(\mathrm{C}_{6} \mathrm{H}_{7} \mathrm{O}\right) \mathrm{H}^{+}\right]$, methyl salicylate $(\mathrm{MeSa})$ as $m / z 153.055\left[\left(\mathrm{C}_{8} \mathrm{H}_{9} \mathrm{O}_{3}\right) \mathrm{H}^{+}\right]$, and eugenol as $m / z 165.092$ $\left[\left(\mathrm{C}_{10} \mathrm{H}_{13} \mathrm{O}_{2}\right) \mathrm{H}^{+}\right]$(Brilli et al., 2011, 2016; Tasin et al., 2012; Maja et al., 2014; Giacomuzzi et al., 2016; Portillo-Estrada et al., 2017; Yener et al., 2016; Misztal et al., 2015). Emissions of IS, MT, and SQT were standardized to $1000 \mu \mathrm{mol} \mathrm{m}{ }^{2} \mathrm{~s}^{-1}$ PAR and $30^{\circ} \mathrm{C}\left(\mathrm{IS}_{\mathrm{S}}, \mathrm{MT}_{\mathrm{S}}, \mathrm{SQT}_{\mathrm{S}}\right)$ using the Guenther et al. (1993) algorithm for $\mathrm{IS}_{\mathrm{S}}$ and Geron et al. (1994) for $\mathrm{MT}_{\mathrm{S}}$ and $\mathrm{SQT}_{\mathrm{S}}$.

$$
\begin{aligned}
& \mathrm{IS}_{\mathrm{S}}=\frac{\mathrm{IS}}{C_{L} \times C_{T}} \\
& C_{L}=\frac{\alpha c_{\mathrm{L} 1 \mathrm{~L}}}{\sqrt{1+\alpha^{2} \times L^{2}}} \\
& C_{T}=\frac{\exp \frac{C_{T 1}\left(T-T_{s}\right)}{\mathrm{RT}_{S} T}}{1+\exp \frac{C_{T 2}\left(T-T_{M}\right)}{\mathrm{RT} T}} \\
& \mathrm{MT}_{\mathrm{S}}=\frac{\mathrm{MT}}{\exp \left(\beta\left(T-T_{S}\right)\right)} \\
& \mathrm{SQT}_{\mathrm{S}}=\frac{\mathrm{SQT}}{\exp \left(\beta\left(T-T_{S}\right)\right)}
\end{aligned}
$$

Here IS, MT, and SQT are emission rates normalized by leaf area at sampling temperature $T(\mathrm{~K})$ and sampling PAR flux $L\left(\mu \mathrm{mol} \mathrm{m}{ }^{-2} \mathrm{~s}^{-1}\right)$ at half plant height; $\alpha=0.0027, c_{L 1}$

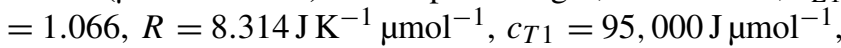

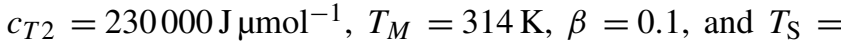
303.15 K (Guenther et al., 1993; Geron et al., 1994).

Mass flow of air $(W)$, transpiration rate $(E)$, net photosynthesis $(A)$, and stomatal conductance $\left(g_{S}\right)$ were calculated accordingly (CIRAS-3 Operation Manual V. 2-01, PP-Systems, 2018).

$$
\begin{aligned}
& W=\left(\frac{V_{0}}{60 \times 10^{3}}\right) \times\left(\frac{1}{22.414}\right) \times\left(\frac{10^{4}}{a}\right)\left[\mathrm{mol} \mathrm{m}^{-2} \mathrm{~s}^{-1}\right] \\
& E=\left[\frac{W \times\left(e_{\text {out }}-e_{\text {in }}\right)}{\left(P-e_{\text {out }}\right)}\right]\left[\mathrm{mol} \mathrm{m}^{-2} \mathrm{~s}^{-1}\right] \\
& A=-\left[\left(\left(C_{\text {out }}-C_{\text {in }}\right) \times W\right)+\left(C_{\text {out }} \times E\right)\right]\left[\mu \mathrm{mol} \mathrm{m}^{-2} \mathrm{~s}^{-1}\right] \\
& e_{\text {leaf }}=6.1365 \times \exp \left[\frac{T_{\text {leaf }} \times(17.502)}{T_{\text {leaf }}+240.97}\right] \\
& r_{\mathrm{S}}=\left[\frac{\left(e_{\text {leaf }}-e_{\text {out }}\right)}{\left(E \times\left(P-\left(e_{\text {leaf }}+e_{\text {out }}\right) / 2\right)\right)}\right]-r_{\mathrm{b}}\left[\mathrm{m}^{2} \mathrm{~s} \mathrm{~mol}^{-1}\right] \\
& g_{\mathrm{S}}=\frac{1}{r_{\mathrm{S}}} \times 10^{3}\left[\mathrm{mmol} \mathrm{m}^{-2} \mathrm{~s}^{-1}\right]
\end{aligned}
$$

Here $V_{0}$ is the volume air flow, $a$ is the leaf area, $e_{\text {in }}$ is the partial water vapor pressure of the air entering the enclosures, $e_{\text {out }}$ is the partial water vapor pressure inside the enclosure, $(P)$ is the atmospheric pressure, $\mathrm{C}_{\mathrm{in}}$ in the concentration of $\mathrm{CO}_{2}$ entering and $\mathrm{C}_{\text {out }}$ is the concentration exiting the enclosure, $e_{\text {leaf }}$ is the saturation vapor pressure at leaf temperature ( $\left.T_{\text {leaf }}\right), r_{\mathrm{s}}$ is the stomatal resistance, and $r_{\mathrm{b}}$ is the boundary layer resistance to water vapor transfer, which was assumed to be zero according to the recommendations of the manufacturer (CIRAS-3 Operation Manual V. 2-01, PP-Systems, 2018).

The ratio of the sum of carbon lost in the form of BVOC $\left(\mathrm{C}_{\mathrm{BVOCs}}\right)$ vs. the uptake of carbon from net photosynthesis 
$\left(\mathrm{C}_{\mathrm{A}}\right)$ was calculated according to Pegoraro et al. (2004), with the BVOCs used to calculate $\mathrm{C}_{\mathrm{BVOCs}}$ given in Table A3.

After $7 \mathrm{~d}$, finishing the emission measurements, all leaves were harvested immediately, imaged with a flatbed scanner (Epson Expression 10 000XL, Epson, Japan), and analyzed with the PC program WinFOLIA 2013 Pro (Regent Instruments Inc., Qúebec, Canada) to determine the leave surface area. About $80 \%$ of the leaves' fresh mass was shockfrozen and crushed in liquid nitrogen for biochemical assays (Sect. 2.3). About $20 \%$ of the leaves per plant were dried for $3 \mathrm{~d}$ in a drying room at $40^{\circ} \mathrm{C}$ to determine dry weight to an accuracy of $\pm 0.001 \mathrm{~g}$ for the calculation of enzyme activity and specific leaf area (SLA) (Table A4).

\subsection{Biochemical assay}

For the interpretation of the emissions of GLVs and shikimate volatiles, enzymatic activities were analyzed additionally to better understand the effect of ozone fumigation during a situation of severe drought. Using foliar materials collected after the $7 \mathrm{~d}$ period of emission measurements (Sect. 2.2) and stored at $-80^{\circ} \mathrm{C}$ until analysis, peroxidase and antioxidant capacity and phenol content (TPhe) were measured. These properties provide additional insights into the response of GLV and shikimate emissions as products of the metabolic process of the enzymatic activity (Betz et al., 2009).

Values from plants after $7 \mathrm{~d}$ of increasing drought $(\mathrm{DS} \times \mathrm{OS}, \mathrm{DS})$ were compared to well-watered control plants $(C)$ and a well-watered set of plants that received ozone fumigation once (OS).

For measurements of peroxidase activities, $0.5 \mathrm{~g}$ plant material, $0.25 \mathrm{~g}$ Polyclar AT (Serva Electrophoresis, Heidelberg, Germany), and $0.25 \mathrm{~g}$ quartz sand (Sigma-Aldrich, Steinheim, Germany) were homogenized in a mortar with $3 \mathrm{~mL}$ $0.1 \mathrm{M}$ potassium phosphate buffer ( $\mathrm{pH}$ 6.0). After removal of solid compounds by centrifugation at $4{ }^{\circ} \mathrm{C}$ and $10000 \times g$ for $10 \mathrm{~min}, 400 \mu \mathrm{L}$ of the supernatant was subjected to gel chromatography with Sephadex G-25 medium (GE Healthcare, Chicago, IL, USA) to remove low-molecular-weight compounds. Peroxidase activity was determined according to the Worthington Manual (1972). Briefly, the enzyme assay contained in a final volume of $1110,1095 \mu \mathrm{L}$ buffer $0.1 \mathrm{M}$ potassium phosphate buffer $+0.003 \%(v / v) \mathrm{H}_{2} \mathrm{O}_{2}(\mathrm{pH} 6.0)$, $5 \mu \mathrm{L}$ enzyme preparation, and $10 \mu \mathrm{L} 1 \%(w / v) o$-dianisidin (Sigma-Aldrich-Aldrich, Vienna Austria) in $\mathrm{MeOH}$.

The activity was determined by measuring the extinction at $460 \mathrm{~nm}$ on a DU-65 spectrophotometer (Beckman Instruments, Brea, CA, USA) in intervals of $30 \mathrm{~s}$ for a period of $6 \mathrm{~min}$. The activity was calculated from the slope in the initial linear portion of the reaction progress curved using an extinction coefficient of $1.13 \times 10^{4} \mathrm{M}^{-1} \mathrm{~cm}^{-1}$ for oxidized $o$-dianisidine (Worthington manual, 1972). The protein content was determined by a modified Lowry procedure (Sandermann and Strominger, 1972) using bovine serum albumin as a standard. All measurements were performed in two technical replicates.

For the determination of the antioxidant capacity and the TPhen, the material was lyophilized and homogenized by grinding to a fine powder in a mortar. A total of $0.25 \mathrm{~g}$ of the lyophilized powder was extracted with $3 \mathrm{~mL}$ distilled water for $1 \mathrm{~h}$ in a cooled water bath during sonication. After centrifugation for $5 \mathrm{~min}$ at $4{ }^{\circ} \mathrm{C}$ and $10000 \times g$, the supernatant was filtered through a Chromafil AO-20/25 polyamide filter (Roth, Karlsruhe, Germany).

The TPhen was determined as described (Wootton-Beard et al., 2011) with some modifications. Briefly, $100 \mu \mathrm{L}$ of the aqueous solution was mixed with $6 \mathrm{~mL}$ distilled water and $500 \mu \mathrm{L}$ Folin-Ciocâlteu reagent (Sigma-Aldrich, Vienna, Austria) (1:1 v/v with distilled water). After equilibration for $8 \mathrm{~min}, 1.5 \mathrm{~mL} 20 \% \mathrm{Na}_{2} \mathrm{CO}_{3}(w / v)$ and $1.9 \mathrm{~mL}$ distilled water were added, and the mixture was incubated at $40^{\circ} \mathrm{C}$ for $30 \mathrm{~min}$. The TPhen was obtained by measuring the absorbance of the mixture at $765 \mathrm{~nm}$ using a freshly prepared standard curve obtained with gallic acid. The results were expressed as microgram gallic acid equivalents per gram of sample. All measurements were performed in technical triplicates.

The in vivo antioxidant activity was determined with Saccharomyces cerevisiae ZIM 2155 as model system following the procedures described in Slatnar et al. (2012), which estimates intracellular oxidation by fluorometric measurements using the ROS-sensitive dye $2^{\prime}, 7^{\prime}$-dichlorofluorescin $\left(\mathrm{H}_{2} \mathrm{DCF}\right)$. A total of $100 \mu \mathrm{L}$ of the aqueous samples was incubated with $10 \mathrm{~mL}$ yeast suspension at their stationary phase in phosphate-buffered saline (PBS, Merck KGaA, Darmstadt, Germany) at a density of $10^{8}$ cells per suspension at $28^{\circ} \mathrm{C}$ and $220 \mathrm{rpm}$ for $2 \mathrm{~h}$. After a centrifugation step at room temperature for $5 \mathrm{~min}$ at $14000 \times g$, the pellet was washed three times with $50 \mathrm{mM}$ potassium phosphate buffer $(\mathrm{pH} 7.8)$ and was finally resuspended in nine volumes of $500 \mu \mathrm{L} 50 \mathrm{mM}$ potassium phosphate buffer ( $\mathrm{pH} 7.8)$ and incubated for $10 \mathrm{~min}$ at $28^{\circ} \mathrm{C}$ and $220 \mathrm{rpm}$ in the dark. After addition of $10 \mu \mathrm{L} \mathrm{H}_{2}$ DCF ( $1 \mathrm{mM}$ stock solution in $96 \%$ ethanol), the mixture was incubated for further $30 \mathrm{~min}$ at $28^{\circ} \mathrm{C}$ and $220 \mathrm{rpm}$. The fluorescence of the yeast cell suspensions was measured at a GloMax ${ }^{\circledR}$ Multi Microplate Reader (Promega, Walldorf, Germany) using excitation and emission wavelengths of 490 and $520 \mathrm{~nm}$, respectively. Values of fluorescence intensity were measured against a blank, in which the sample was replaced with water. Data are expressed as relative fluorescence intensity, where the values obtained with the blank are defined as 1 . Values lower than 1 indicate a higher antioxidant activity than the blank (Slatnar et al., 2012). All measurements were performed in two technical replicates. 


\subsection{Statistical analyses}

Emission rates, physiological parameters, means, and standard deviation were calculated with MATLAB (MATLAB and Statistics Toolbox Release 2017a; The MathWorks, Inc., Natick, MA, United States). All leaf gas exchange $\left(\mathrm{CO}_{2}\right.$ and $\mathrm{H}_{2} \mathrm{O}$ ) and BVOC flux measurements collected over the $7 \mathrm{~d}$ period for the set DS and DS $\times$ OS were aggregated into four ranges of SWP (R1: 0.00 to $-1.40 \mathrm{MPa}$; $\mathrm{R} 2$ : -1.45 to $-2.85 \mathrm{MPa}$; R3: -2.90 to $-4.30 \mathrm{MPa}$; R4: -4.35 to $-6.00 \mathrm{MPa}$ ) to perform statistical analysis using the Wilcoxon rank sum test. To test for significant differences in the biochemical markers, a one-way ANOVA test was used. For both tests $p$ values below 0.05 were considered significant.

\section{Results and discussions}

\subsection{Stomatal closure and net photosynthesis}

SWP was measured daily and used as a drought stress indicator to study the evolution of $Q$. robur under continuously increasing drought condition. All six trees began the experiment with a high to moderate mean SWP of $-0.9 \mathrm{MPa}$ (Brüggemann and Schnitzler, 2002) and reached low values on the order of $-5.5 \mathrm{MPa}$ after $7 \mathrm{~d}$ of continuously increasing drought stress. Mean and standard deviation of stomatal conductance, net photosynthesis, leaf temperature, and SWP as well as notes for statistically significant differences are summarized in Table 1 for the four drought stress ranges defined in Sect. 2.4. The mean stomatal conductance $\left(g_{\mathrm{S}}\right)$ of DS $\times$ OS was $20.2 \mathrm{mmol} \mathrm{m}^{-2} \mathrm{~s}^{-1}$ in R1 and decreased to $6.8 \mathrm{mmol} \mathrm{m}^{-2} \mathrm{~s}^{-1}$ in R2 (Table 1). For DS it was $42.4 \mathrm{mmol} \mathrm{m}^{-2} \mathrm{~s}^{-1}$ in R1 and decreased to $6.6 \mathrm{mmol} \mathrm{m}^{-2} \mathrm{~s}^{-1}$ in R2. For both sets the reduction of $g_{\mathrm{S}}$ and SWP between R1 and R4 was significant ( $p$ value 0.02 and 0.05 for DS and DS $\times$ OS, respectively). R1, shown in Fig. 2a, includes values of trees fumigated with ozone $(\mathrm{DS} \times \mathrm{OS})$ from the first and the second days of analysis, because, for this set, SWP had not changed much during these $2 \mathrm{~d}$. Differently, for DS, R1 includes only measurements of the first day. The values collected during the second day of analysis, for the set DS, is assigned to R2, because we observed a decrease in SWP between the first and second days of measurement. This shows that trees of DS $\times$ OS closed their stoma quickly at higher stem water potential after the first ozone fumigation session and confirms what was reported in other studies that moderate ozone concentrations can induce partially closed stomata (Khatamian et al., 1973; Farage et al., 1991; Wittig et al., 2007). A partial stomatal closure prevented excessive water loss through stomatal openings (Pinheiro and Chaves, 2011; McDowell et al., 2008; Allen et al., 2010) during drought stress and enhanced the closure with ozone, allowing DS $\times$ OS plants to better survive the increased drought. Kobayashi et al. (1993) consider the interactive effects of $\mathrm{O}_{3}$ and drought stress using a growth model of soybeans, finding that ozone fumigation reduces or postpones drought stress, similar to the findings of this experiment.

Figure $2 \mathrm{~b}$ shows a decrease in net photosynthesis $(A)$ with the increase in the stress for both sets, especially between $\mathrm{R} 1$ and $\mathrm{R} 2$, whereas the values in R3 and R4 are close to zero. In R1, $A$ presented the same differences exposed for $g_{\mathrm{S}}$ between the sets. Our results are different from the findings of Tjoelker et al. (1995) and Paoletti (2005), where stomatal conductance and photosynthesis are shown to decouple at moderate ozone exposure due to direct damage to biochemical carboxylation, caused by chronic ozone exposure.

The ratio of $\mathrm{C}_{\mathrm{BVOCS}}$ and $\mathrm{C}_{\mathrm{A}}$ is shown in Fig. 3. IS, the dominant BVOC (averagely $96 \%$ of the total emissions), and mean standardized IS emissions of DS $\times$ OS-treated plants were consistently higher in all SWP ranges compared to DS alone (Fig. 4), thus showing the difference between DS and $\mathrm{DS} \times \mathrm{OS}$ in $\mathrm{C}_{\mathrm{BVOCs}} / C_{\mathrm{A}}$ in the highest $\mathrm{SWP}$ ratio range. Initially, at low drought stress (R1), 3\%-7\% of the assimilated carbon was lost as emitted BVOC, which matches findings in other studies (Sharkey et al., 1991; Baldocchi et al., 1995; Monson and Fall, 1989; Fang et al., 1996), showing that $\sim 2 \%$ of carbon assimilated is lost as IS $\left(\mathrm{C}_{\mathrm{IS}} / C_{\mathrm{A}}\right)$ under unstressed conditions and at $30^{\circ} \mathrm{C}$. As $\mathrm{CO}_{2}$ assimilation rate decreased quickly and BVOC emission (especially isoprene emission) stayed elevated, the ratio of lost vs. fixed carbon increased to $20 \%$ for DS and $16 \%$ for DS $\times$ OS in R2. Pegoraro et al. (2004) reported a carbon loss on the order of $50 \%$ for SWP of $-2 \mathrm{MPa}$, in a drought experiment with Quercus virginiana. In R3, the increasing stress corresponded to ratios of 0.7 and 1.03 for DS and DS $\times$ OS, respectively. Alternative carbon sources for isoprene biosynthesis under drought stress are thus proposed for DS $\times$ OS. For example, extrachloroplastic origin or chloroplastic starch (Karl et al., 2002; Kreuzwieser et al., 2002; Funk et al., 2004; Affek and Yakir, 2003; Schnitzler et al., 2004; Rosenstiel et al., 2003) can sustain carbon sources for isoprene production. At very high drought stress (R4) this ratio decreased again to 0.4 in DS and 0.8 in DS $\times$ OS.

\subsection{BVOC emissions}

To give a general overview on BVOC emissions for both sets, Fig. 5a and $b$ show the total mass spectra ranging from 40 $220 \mathrm{amu}$ for the first and last days of measurement for DS and DS $\times$ OS, respectively. Figure $5 \mathrm{c}$ shows relative changes of the mass spectra between the first and last days of measurements. The mass range $80-110 \mathrm{amu}$, hosting many massto-charge ratios associated with GLVs, showed the strongest difference between the two sets. Plants exposed to ozone and drought stress (DS $\times$ OS) exhibited smaller increases in this mass range compared to drought-stressed (DS) plants. Changes in emissions or lack thereof for IS, MT, SQT, and 
Table 1. Mean and standard deviation are in parentheses for stomatal conductance $\left(g_{\mathrm{S}}\right)$, net photosynthesis $(A)$, leaf temperature $\left(T_{\text {leaf }}\right)$, and stem water potential (SWP) divided into four ranges of SWP (R1: 0.00 to $-1.40 \mathrm{MPa}$; R2: -1.45 to $-2.85 \mathrm{MPa}$; $\mathrm{R} 3$ : -2.90 to $-4.30 \mathrm{MPa}$; $\mathrm{R} 4:-4.35$ to $-6.00 \mathrm{MPa})$.

\begin{tabular}{|c|c|c|c|c|c|c|c|c|}
\hline & \multicolumn{2}{|c|}{$\mathrm{R} 1$} & \multicolumn{2}{|c|}{$\mathrm{R} 2$} & \multicolumn{2}{|c|}{$\mathrm{R} 3$} & \multicolumn{2}{|c|}{$\mathrm{R} 4$} \\
\hline$g_{\mathrm{S}}\left[\mathrm{mmol} \mathrm{m}^{-2} \mathrm{~s}^{-1}\right]$ & $42.4(28.9)^{\mathrm{a}}$ & $20.2(13.8)^{\mathrm{c}}$ & $6.6(4.9)$ & $6.8(2.7)$ & $3.8(0.8)$ & $3.3(0.4)$ & $3.9(0.7)^{\mathrm{a}}$ & $2.9(0.1)^{\mathrm{c}}$ \\
\hline$T_{\text {leaf }}[\mathrm{K}]$ & $302.3(1.9)$ & $303.0(1.7)$ & $302.5(1.0)^{\mathrm{b}}$ & $301.3(0.6)^{\mathrm{b}}$ & $302.1(0.9)$ & $302.6(1.2)$ & $301.1(1.1)$ & $302.7(0.2)$ \\
\hline SWP [MPa] & $-0.9(0.2)^{\mathrm{a}}$ & $-0.9(0.1)^{\mathrm{c}}$ & $-2.0(0.1)$ & $-2.3(0.2)$ & $-3.3(0.2)$ & $-3.6(0.5)$ & $-5.5(0.5)^{\mathrm{a}}$ & $-5.4(0.7)^{\mathrm{c}}$ \\
\hline
\end{tabular}

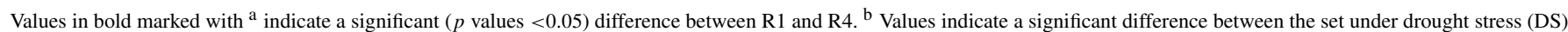
and the set under drought stress with ozone treatment (DS $\times$ OS). Values marked with ${ }^{\mathrm{c}}$ indicate close-to-significant differences with $p$ values of $0.05-0.06$ between 1 and R4.
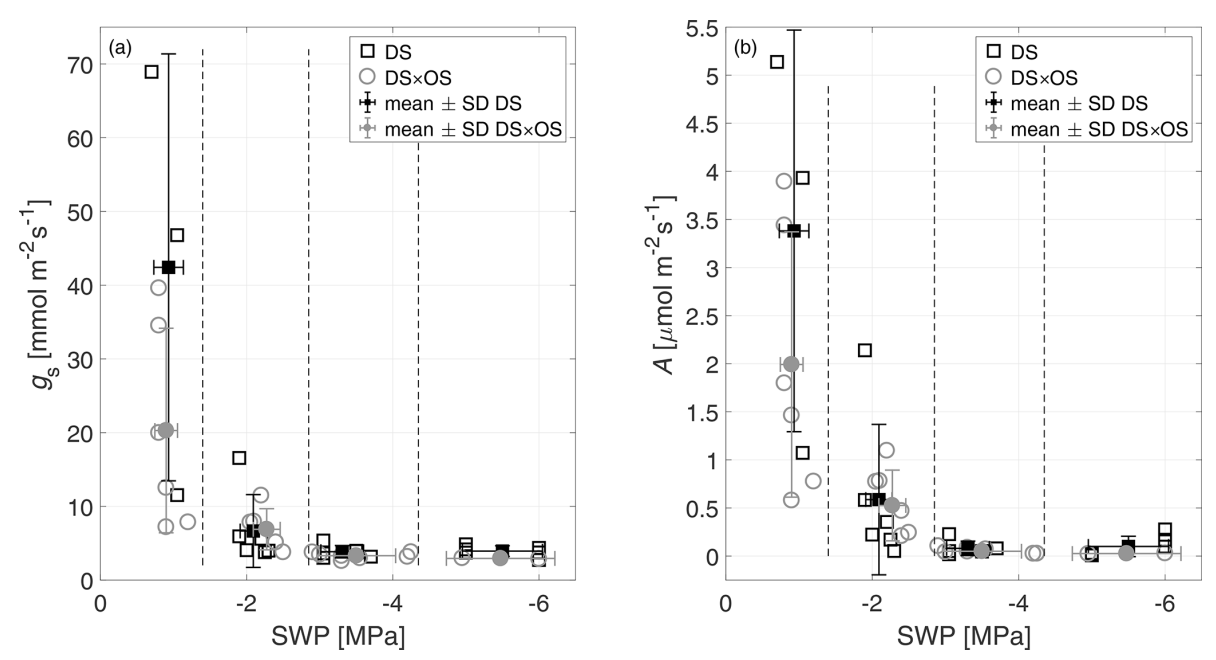

Figure 2. (a) Stomatal conductance $\left(g_{S}\right)$ and (b) net photosynthesis $(A)$ of all trees as a function of stem water potential (SWP). Empty markers represent individual trees where the black squares represent trees out of the set under drought stress (DS) and the gray circles out of the set under drought stress with ozone treatment $(\mathrm{DS} \times \mathrm{OS})$. Filled squares and circles represent means calculated for each SWP range with the corresponding standard deviation. SWP ranges are separated by vertical dashed lines.

stress-related BVOCs are investigated in further detail below and are summarized in Table 2.

\subsubsection{Isoprene emissions}

Q. robur is generally classified as a high-IS-emitting (Benjamin and Winer, 1998; Lehning et al., 2002) and mediumto low-MT-emitting and low-SQT-emitting species (Owen et al., 1997; Karl et al., 2009; Steinbrecher et al., 2009). IS is emitted by plants and synthesized by the enzyme isoprene synthase (Silver and Fall, 1991) and via the 2-methylery-thritol 4-phosphate (MEP) pathway (Lichtenthaler et al., 1997; Lichtenthaler, 1999; Schwender et al., 1997) in chloroplasts (Wildermuth and Fall, 1996, 1998). Figure 4 shows standardized isoprene emissions $\left(\mathrm{IS}_{\mathrm{S}}\right)$ as a function of drought stress for all investigated trees. In the range of SWP R1 the plants were in a low- to no-water-stress condition (Brüggemann and Schnitzler, 2002). Whereas $g_{S}$ and $A$ (Fig. 2a and b) decreased rapidly with increasing drought stress and bottom out at $-3 \mathrm{MPa}$, isoprene emis- sions decreased much slower, reaching close-to-zero emissions at R4. IS $\mathrm{S}$ in R1 was 12.8 and $18.0 \mathrm{nmol} \mathrm{m}^{-2} \mathrm{~s}^{-1}$ for $\mathrm{DS}$ and $\mathrm{DS} \times \mathrm{OS}$, respectively. In $\mathrm{R} 4$ the mean $\mathrm{IS}_{\mathrm{S}}$ was $1.7 \mathrm{nmol} \mathrm{m}^{-2} \mathrm{~s}^{-1}$ for DS and $3.9 \mathrm{nmol} \mathrm{m}^{-2} \mathrm{~s}^{-1}$ for DS $\times$ OS.

The fact that $\mathrm{IS}_{\mathrm{S}}$ emissions remain higher in $\mathrm{DS} \times \mathrm{OS}$ for R1 and R2 compared to DS suggests that overall isoprene production within the leaves must have remained high in response to ozone. High IS fluxes due to ozone treatment are also reported in other studies (Fares et al., 2006; Velikova et al., 2005; Kanagendran et al., 2018).

An increase in IS with moderate stress was observed by Pegoraro et al. (2004) and Beckett et al. (2012), who related this finding to an increase in leaf temperatures as a consequence of stomatal closure. In contrast, a nonsignificant increase was observed in the leaf temperatures, suggesting IS emissions of DS $\times$ OS in R2 being a result of a temperatureindependent isoprene production.

The decrease in $A$ with decreasing SWP, particularly at mild drought stress (Fig. 2b), is much more pronounced than 


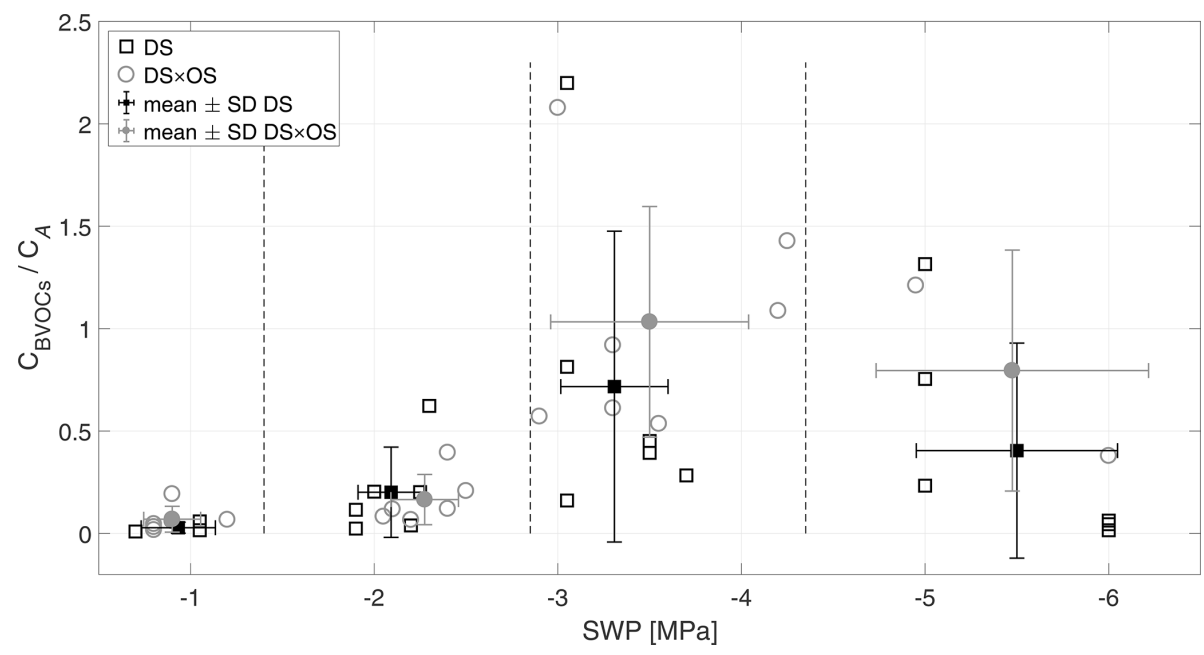

Figure 3. Ratio of sum of carbon emitted by all analyzed BVOCs $\left(\mathrm{C}_{\mathrm{BVOCs}}\right)$ and the sum of carbon uptake via net photosynthesis $\left(\mathrm{C}_{\mathrm{A}}\right)$ versus the stem water potential (SWP). Empty markers represent individual trees where the black squares represent trees out of the set under drought stress (DS) and the gray circles out of the set under drought stress with ozone treatment (DS $\times$ OS). Filled squares and circles represent means calculated for each SWP range with the corresponding standard deviation. SWP ranges are separated by vertical dashed lines.

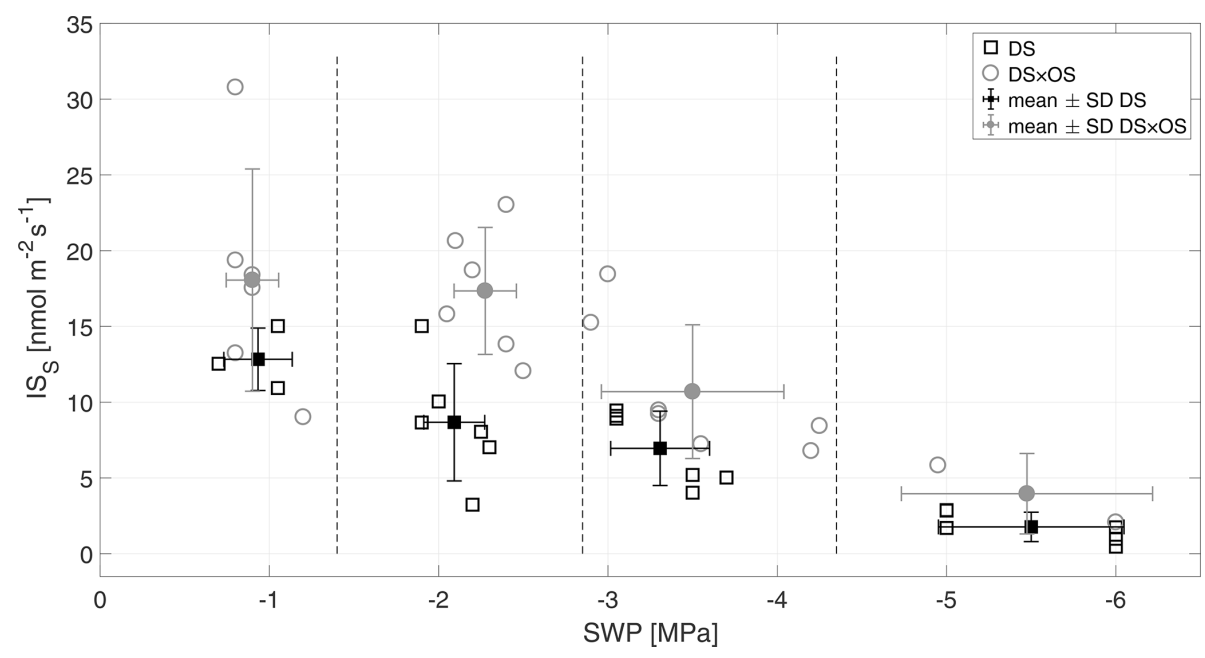

Figure 4. Standardized isoprene emission $\left(\mathrm{IS}_{\mathrm{S}}\right)$ versus stem water potential (SWP). Empty markers represent individual trees where the black squares represent trees out of the set under drought stress (DS) and the gray circles out of the set under drought stress with ozone treatment $(\mathrm{DS} \times \mathrm{OS})$. Filled squares and circles represent means calculated for each SWP range with the corresponding standard deviation. SWP ranges are separated by vertical dashed lines.

the decrease in $\mathrm{IS}_{\mathrm{S}}$ emission rates (Fig. 4). Similar results are found for leaf level measurements of $Q$. robur (Brüggemann and Schnitzler, 2002), Populus alba (Brilli et al., 2007), and Quercus virginiana (Pegoraro et al., 2004) as well as on the ecosystem scale in the Ozarks region in the central US (Seco et al., 2015).

Even though the rate of photosynthetic carbon assimilation declined much faster under drought than IS, a substantial decline of IS was also seen as drought progressed. Drought stress has been found to be one of the stronger influencing factors affecting photosynthesis but had often only limited influence on IS emission rates (Tingey et al., 1981; Sharkey and Loreto, 1993; Fang et al., 1996).

In young hybrid poplars (Populus deltoides '55/56' $\times P$. deltoides 'Imperial'), the combined application of elevated ozone and drought decreases isoprene emission, whereas drought alone increases the emission, and ozone alone decreases it (Yuan et al., 2016).

Studies report that volatile isoprenoids strengthen cellular membranes, thus maintaining the integrity of the thylakoidembedded photosynthetic apparatus, and have a generic antioxidant action by deactivating ROS around and inside leaves and thus indirectly reduce the oxidation of mem- 
Table 2. Mean and standard deviation for standardized isoprene emissions $\left(\mathrm{IS}_{\mathrm{S}}\right.$ ), standardized monoterpene emissions (MT $)$, standardized sesquiterpene emissions ( $\left.\mathrm{SQT}_{\mathrm{S}}\right)$, sum of GLV $(\Sigma \mathrm{GLV})$, and sum of shikimate ( $\Sigma$ shikimate) for each set divided by range of stem water potential (SWP) (R1: 0.00 to $-1.40 \mathrm{MPa}$; R2: -1.45 to $-2.85 \mathrm{MPa}$; R3: -2.90 to $-4.30 \mathrm{MPa}$; 4 : -4.35 to $-6.00 \mathrm{MPa}$ ).

\begin{tabular}{|c|c|c|c|c|c|c|c|c|}
\hline & \multicolumn{2}{|c|}{ R1 } & \multicolumn{2}{|c|}{$\mathrm{R} 2$} & \multicolumn{2}{|c|}{ R3 } & \multicolumn{2}{|c|}{ R4 } \\
\hline & DS & $\mathrm{DS} \times \mathrm{OS}$ & DS & $\mathrm{DS} \times \mathrm{OS}$ & DS & $\mathrm{DS} \times \mathrm{OS}$ & DS & $\mathrm{DS} \times \mathrm{OS}$ \\
\hline $\mathrm{IS}_{\mathrm{S}}\left[\mathrm{nmol} \mathrm{m}^{-2} \mathrm{~s}^{-1}\right]$ & $12.8(2.0)^{\mathrm{a}}$ & $18.0(7.3)^{\mathrm{c}}$ & $8.6(3.8)^{\mathrm{b}}$ & $17.3(4.1)^{\mathrm{b}}$ & $6.9(2.4)$ & $10.6(4.4)$ & $1.7(0.9)^{\mathrm{a}}$ & $3.9(2.6)^{\mathrm{c}}$ \\
\hline $\mathrm{MT}_{\mathrm{S}}\left[\mathrm{nmol} \mathrm{m}^{-2} \mathrm{~s}^{-1}\right]$ & 0.010 & 0.036 & 0.009 & 0.023 & 0.010 & 0.015 & 0.033 & 0.047 \\
\hline & $(0.002)^{\mathrm{a}}$ & $(0.026)$ & $(0.004)$ & $(0.013)$ & $(0.002)$ & $(0.010)$ & $(0.014)^{\mathrm{a}}$ & $(0.012)$ \\
\hline $\mathrm{SQT}_{\mathrm{S}}$ & 0.002 & 0.002 & 0.003 & 0.001 & 0.005 & 0.007 & 0.014 & 0.035 \\
\hline$\left[\mathrm{nmol} \mathrm{m}^{-2} \mathrm{~s}^{-1}\right]$ & $(0.001)^{\mathrm{a}}$ & $(0.001)^{\mathrm{c}}$ & $(0.002)$ & $(0.001)$ & $(0.003)$ & $(0.008)$ & $(0.005)^{\mathrm{a}}$ & $(0.007)^{\mathrm{c}}$ \\
\hline$\Sigma$ GLV & 0.002 & 0.003 & 0.004 & 0.001 & 0.002 & 0.001 & 0.032 & 0.009 \\
\hline$\left[\mathrm{nmol} \mathrm{m}^{-2} \mathrm{~s}^{-1}\right]$ & $(0.001)^{\mathrm{a}}$ & $(0.004)$ & $(0.005)^{b}$ & $(0.003)^{b}$ & $(0.002)$ & $(0.001)$ & $(0.045)^{\mathrm{a}}$ & $(0.010)$ \\
\hline$\Sigma$ shikimate & 0.001 & 0.003 & 0.001 & 0.003 & 0.004 & 0.008 & 0.003 & 0.009 \\
\hline$\left[\mathrm{nmol} \mathrm{m}^{-2} \mathrm{~s}^{-1}\right]$ & $(0.001)$ & $(0.001)^{\mathrm{c}}$ & $(0.002)$ & $(0.003)$ & $(0.002)$ & $(0.012)$ & $(0.001)$ & $(0.001)^{\mathrm{c}}$ \\
\hline
\end{tabular}

Values in bold marked with ${ }^{\mathrm{a}}$ indicate a significant $\left(p\right.$ values $<0.05$ ) difference between R1 and R4. ${ }^{\mathrm{b}}$ Values indicate a significant difference between the set under drought stress (DS) and the set under drought stress with ozone treatment (DS $\times$ OS). Values marked with ${ }^{\mathrm{c}}$ indicate close-to-significant differences with $p$ values of $0.05-0.06$ between $\mathrm{R} 1$ and $\mathrm{R} 4$.

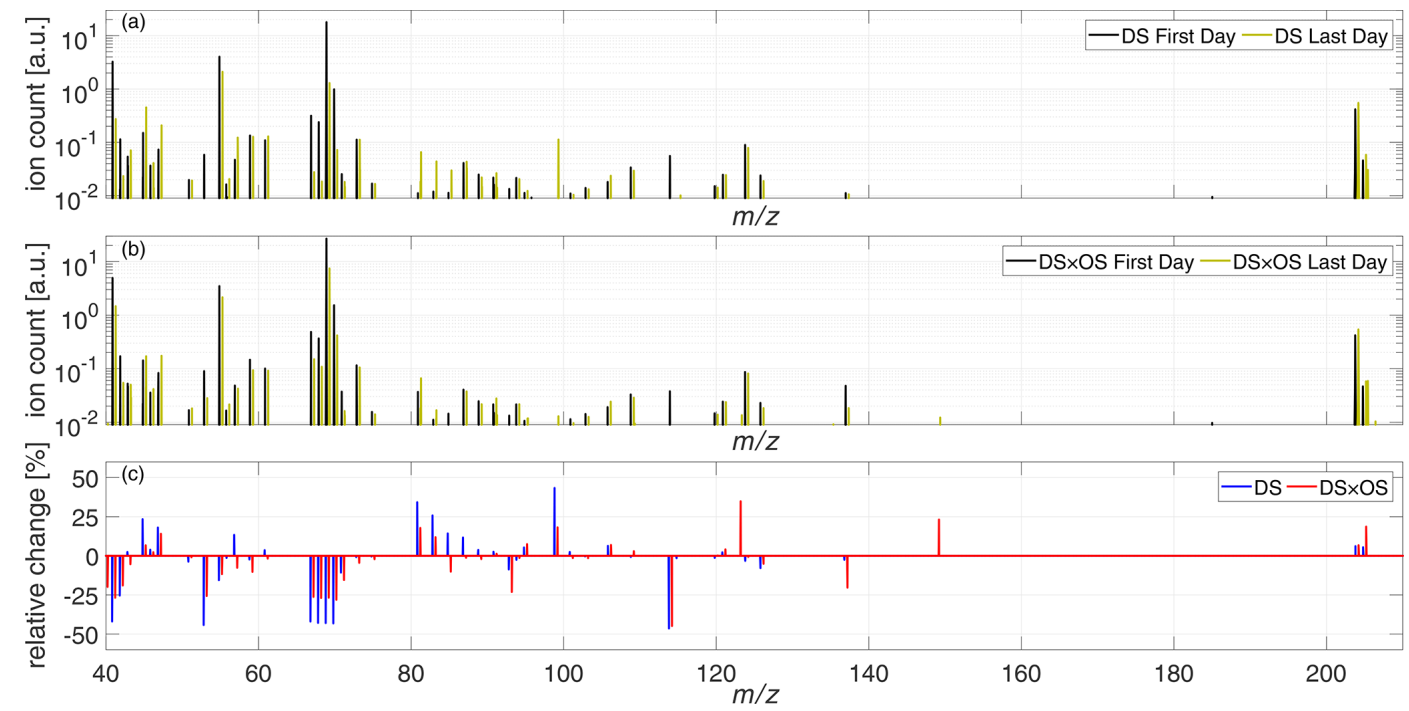

Figure 5. Mean mass spectra of the set under drought stress (DS) (a) and the set under drought stress with ozone fumigation (DS $\times$ OS) (b), on the first (black) and last (yellow) days of measurement. (c) Relative change in the mass spectra between the last and the first days of analysis for DS (blue) and DS $\times$ OS (red).

brane structures and macromolecules (Singsaas et al., 1997; Loreto and Velikova, 2001; Affek and Yakir, 2002; Loreto and Schnitzler, 2010; Velikova et al., 2012).

\subsubsection{Terpenoid emissions}

Monoterpenes (MT) and sesquiterpenes (SQT), other classes of isoprenoids, are synthesized through the condensation of isoprene units (allylic isomer dimethylallyl diphosphate, DMAPP, and isoprenyl diphosphate, IPP) (Ruzicka, 1953; Cheng et al., 2007). Geranyl diphosphate (GDP) is the precursor of all MT isomers. GDP is formed from IPP and DMAPP driven enzymatically by GDP synthase (Mahmoud and Croteau, 2002). Farnesyl diphosphate (FDP) synthases adds two molecules of IPP to DMAPP for the formation of the SQT precursors, $\mathrm{C}_{15}$ diphosphate (Cheng et al., 2007). Figure 6a shows $\mathrm{MT}_{\mathrm{S}}$ and Fig. $6 \mathrm{~b} \mathrm{SQT}_{\mathrm{S}}$ as a function of SWP. Mean $\mathrm{MT}_{\mathrm{S}}$ values for DS and DS $\times$ OS were $1.0 \times 10^{-2} \mathrm{nmol} \mathrm{m}^{-2} \mathrm{~s}^{-1}$ and $3.6 \times 10^{-2} \mathrm{nmol} \mathrm{m}^{-2} \mathrm{~s}^{-1}$, respectively, at R1. With the increase in drought stress (R3) DS $\times$ OS decreased to $1.5 \times 10^{-2} \mathrm{nmol} \mathrm{m}^{-2} \mathrm{~s}^{-1}$ while DS emissions remained stable $\left(1.0 \times 10^{-2} \mathrm{nmol} \mathrm{m}^{-2} \mathrm{~s}^{-1}\right)$. For higher drought stress (R4) both sets showed an increase in MT emissions reaching $3.3 \times 10^{-2} \mathrm{nmol} \mathrm{m}^{-2} \mathrm{~s}^{-1}$ for DS and $4.7 \times 10^{-2} \mathrm{nmol} \mathrm{m}^{-2} \mathrm{~s}^{-1}$ for DS $\times$ OS. 

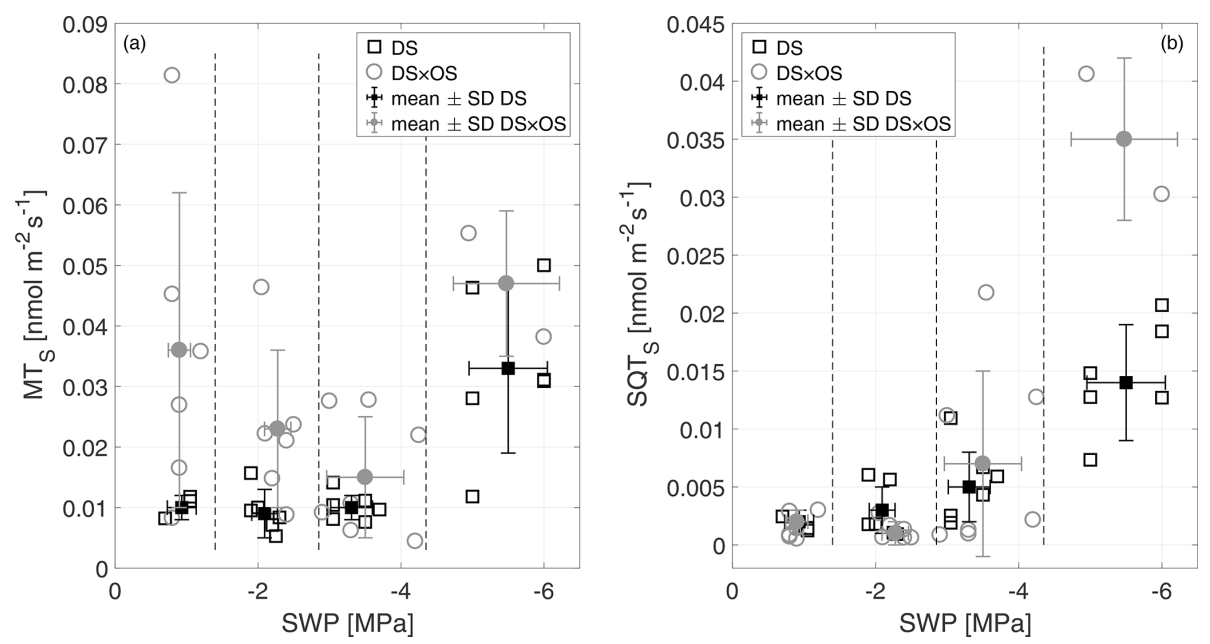

Figure 6. Standardized monoterpene $\left(\mathrm{MT}_{\mathrm{S}}\right)(\mathbf{a})$ and sesquiterpene $\left(\mathrm{SQT}_{\mathrm{S}}\right)(\mathbf{b})$ emissions versus stem water potential (SWP). Empty markers represent individual trees where the black squares represent trees out of the set under drought stress (DS) and the gray circles out of the set under drought stress with ozone treatment $(\mathrm{DS} \times \mathrm{OS})$. Filled squares and circles represent means calculated for each SWP range with the corresponding standard deviation. SWP ranges are separated by vertical dashed lines.

Loreto et al. (2004) demonstrated that ozone can stimulate the emission of monoterpenes in $Q$. ilex but that ozone has no effect on photosynthesis nor on any other physiological parameter when Mediterranean oak plants are exposed to mild and repeated as well as acute ozone stress.

In this experiment MT emissions from $Q$. robur increased in DS and DS $\times$ OS trees. In the case of DS, there was a positive effect of drought, with a significant increase in MT emissions, although there was a drastic decrease in IS emissions when the water deficit was severe. These observations contrast those by Llusiá and Peñuelas (1998) for Q. coccifera reporting a decrease in MT emissions under severe drought conditions. This could be due to the fact that in the case of $Q$. coccifera no specific terpene storage structures are present in leaves, while they are present in $Q$. robur (Karl et al., 2009).

In both sets $\mathrm{SQT}_{\mathrm{S}}$ emissions remained close to zero down to a SWP of $-3 \mathrm{MPa}$. SQT $\mathrm{S}$ emissions increase with increasing drought stress, reaching a mean value of $1.4 \times 10^{-2} \mathrm{nmol} \mathrm{m}^{-2} \mathrm{~s}^{-1}$ for DS and $3.5 \times 10^{-2} \mathrm{nmol} \mathrm{m}^{-2} \mathrm{~s}^{-1}$ for DS $\times$ OS in R4. The increase in $\mathrm{SQT}_{\mathrm{S}}$ in the set with ozone began 1d later than in the set without ozone fumigation.

Stress on plants can induce SQT emissions (Toome et al., 2010; Maes and Debergh, 2003; Ibrahim et al., 2006). Ormeño et al. (2007) observe a reduction of sesquiterpenes with drought stress for a variety of plant species including $Q$. coccifera. For $Q$. robur we see an increase in SQT emissions under conditions of severe drought.

The release in SQT from leaves can be triggered when plants face stress due to oxidative processes in leaves, indicating that damaging effects inside the plants start to occur (Beauchamp et al., 2005; Bourtsoukidis et al., 2012). Unlike MT, SQTs do not provide an additional barrier to plant dam- age during severe water stress (Palmer-Young et al., 2015). This is due to their different physicochemical characteristics and the different pathways that produce them (Niinemets et al., 2004; Umlauf et al., 2004). In the case of SQT emissions, the parallel occurrence of two stresses (ozone and increased drought) generally led to an increase in emissions. In fact, the higher SQT emissions in DS $\times$ OS compared to DS may have been due to ozone, similar to those reported in Beauchamp et al. (2005).

\subsubsection{GLV and shikimate emissions}

GLVs are released once the membrane is injured independently of the stress that caused the damage (Heiden et al., 2003). The release in GLVs is related to the degree of damage, and high emissions are linked to high membrane degradation (Fall et al., 1999; Beauchamp et al., 2005; Behnke et al., 2009).

In this experiment, the $\Sigma$ GLV increased for both sets in R4 (Fig. 7a). Within $\Sigma$ GLV $m / z$ 99.080, attributable to hexenal isomers, showed the strongest increase in DS (mean value of $m / z 99.080$ in R4 was $68 \%$ of the $\Sigma$ GLV emission). Within the cascade of GLV production, $(E)$-2-hexenal and $(Z)-3$-hexenal are typically the ones appearing first (Fall et al., 1999).

DS $\times$ OS, on the other hand, showed an increase in shikimate compounds (Fig. 7b) at SWP $<-3 \mathrm{MPa}$; DS showed a similar but less pronounced trend. The $\Sigma$ shikimate was dominated by methyl salicylate (MeSa) across the entire SWP range for DS and in R1-R3 for DS $\times$ OS. R4 of DS $\times$ OS was dominated by $m / z 95.050$ (matching the exact mass of protonated phenol, $\left.\mathrm{C}_{6} \mathrm{H}_{7} \mathrm{O}^{+}\right)$. MeSa is considered a volatilestress-signaling molecule from plants (Karl et al., 2008). 

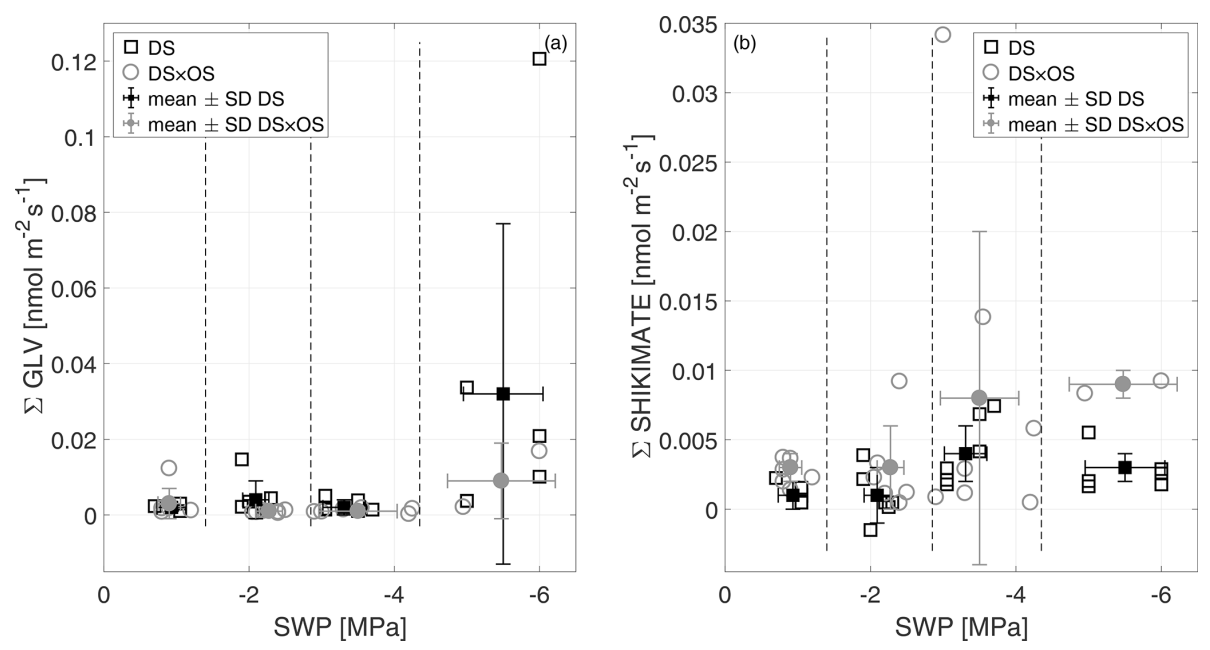

Figure 7. The sum of green leaf volatiles ( $\Sigma$ GLV) (a) and the sum of shikimate ( $\Sigma$ shikimate) compound (b) emissions versus stem water potential (SWP). Empty markers represent individual trees where the black squares represent trees out of the set under drought stress (DS) and the gray circles out of the set under drought stress with ozone treatment (DS $\times$ OS). Filled squares and circles represent the mean values calculated for each SWP range with the corresponding standard deviation. SWP ranges are separated by vertical dashed lines.

High emissions of MeSa are also found in the case of the tobacco plant (Nicotiana tabacum L. cultivars) in both $\mathrm{O}_{3}$ sensitive and $\mathrm{O}_{3}$-tolerant cultivars exposed to ozone at high concentrations (Heiden et al., 1999; Beauchamp et al., 2005).

Observing the increase in GLV emissions in DS and shikimate emissions in DS $\times$ OS was important to understand how ozone affected the $Q$. robur trees exposed to drought stress. The impact of exposure to high ozone concentrations on ROS production was not significant and not associated with membrane lesions in Pellegrini et al. (2019). In this experiment, GLV emissions in R4 were not significantly different from $\mathrm{R} 1$, with low values in ozone-treated plants (DS $\times$ OS), while plants that were exposed to drought only (DS) exhibited higher emissions, with a significant increase in GLV emissions between R1 and R4 (Table 2). The observations of this experiment can be interpreted such that plants did not suffer from detrimental effects due to acute ozone exposure yet (e.g., Beauchamp et al., 2005) but that mild ozone exposure can potentially delay effects of drought stress and help maintain membrane structure and integrity.

The activation of an efficient free-radical-scavenging system can minimize the adverse effects of a general peroxidation (Miller et al., 1999). This was not the case in DS, where exposure to severe water stress alone led to an increase in GLV emissions, suggesting the onset of physical membrane damage, as the enhancement of the lipoxygenase activity, in accordance with other studies (Ebel et al., 1995; WendaPiesik, 2011). In addition to the lipoxygenase and hydroperoxide lyase systems producing GLVs, the phenylpropanoid pathway signals plant responses to stimuli induced by abiotic factors (Dixon and Paiva, 1995; Baier et al., 2005; Heath, 2008; Vogt, 2010), but drought stress alone does not induce the phenylpropanoid pathway in $Q$. robur (Pellegrini et al., 2019).

On the other hand, DS $\times$ OS showed a small increase in GLV only at the highest stress level. We take this to indicate that ozone has the potential to inhibit drought stress damage and therefore the emissions of GLV, by stimulating the phenylpropanoid pathway to form an antioxidant protection for chloroplasts (Pellegrini et al., 2019). The GLV emissions in DS $\times$ OS are initially inhibited during the onset of drought. While ozone fumigation initially inhibits the activation of the lipoxygenase and the hydroperoxide lyase pathway indirectly, these pathways are clearly triggered during the progression of severe drought stress (R4) (Heiden et al., 2003; Matsui, 2006). Cabané et al. (2004) report that, in poplar leaves, ozone exposure stimulates not only the enzymes of the phenylpropanoid pathway but also the activity of the enzyme SHDH of the shikimate pathway that yields TPhe in fully developed leaves.

To better understand the emissions of GLVs and shikimate volatiles, we looked at antioxidant capacity, total phenol content, and peroxidase activity summarized in Table 3 . No significant differences were found for antioxidant capacity between the sets DS and DS $\times$ OS and their corresponding references $C$ and OS. However, it appeared that the OS had the highest oxidizing capacity. TPhen in the fully developed leaves was significantly higher in the two groups experiencing drought stress (DS, DS $\times$ OS) than in those with no drought stress $(C$, OS). Pellegrini et al. (2019) found a significant difference in TPhen content in well-watered plants with the increase in ozone and a decrease at moderate drought and no significant influence of ozone on TPhen during severe drought in $Q$. robur. The results of our study showed no significant decrease in TPhen due to ozone fumigation in 
Table 3. Mean and standard deviation of antioxidant capacity, total phenol content (TPhen), peroxidase activity for well-watered sets with $(\mathrm{OS})$ and without $(C)$ ozone treatment, and sets under severe drought stress with (DS $\times$ OS) and without (DS) ozone treatment after $7 \mathrm{~d}$ of measurements.

\begin{tabular}{lrrr}
\hline & $\begin{array}{r}\text { Antioxidant capacity } \\
{\left[(F \text { OD per sample })(F \text { OD per control })^{-1}\right]}\end{array}$ & $\begin{array}{r}\text { TPhen } \\
{\left[\text { grGAEequiv. } \mathrm{kg}^{-1}(\mathrm{DW})\right]}\end{array}$ & $\begin{array}{r}\text { Peroxidase activity } \\
{\left[\mu \mathrm{mol} \mathrm{s}^{-1} \mathrm{~kg}^{-1}(\mathrm{DW})\right]}\end{array}$ \\
\hline$C$ & $0.9(0.1)$ & $35.6(11.7)^{\mathrm{e}}$ & $0.9(0.7)$ \\
OS & $0.8(0.04)$ & $25.8(11.7)^{\mathrm{f}}$ & $0.6(0.3)$ \\
DS & $1.0(0.1)$ & $86.5(24.1)^{\mathrm{e}}$ & $0.9(0.3)$ \\
DS $\times$ OS & $1.0(0.1)$ & $77.1(9.2)^{\mathrm{f}}$ & $0.8(0.4)$ \\
\hline
\end{tabular}

Values in bold marked with ${ }^{\mathrm{e}}$ represent values with significant $\left(p\right.$ value $<0.05$ ) differences between $C$ and DS. ${ }^{\mathrm{f}}$ Values with significant differences between OS and DS $\times$ OS.

both well-watered and severe drought conditions (R4) (OS, DS $\times$ OS). Peroxidase activity analysis did not show significant differences between the four sets. This is in accordance with the findings of Schwanz and Polle (2001), who found that unspecific peroxidase activities are not affected by drought stress in $Q$. robur.

\section{Conclusions}

The changes in BVOC emissions of $Q$. robur subject to continuously increasing drought were investigated, and differences in the drought progression were observed in plants with and without ozone fumigation. Stomatal conductance and net photosynthesis showed a fast reaction to increasing drought, closing stomata and reducing $\mathrm{CO}_{2}$ uptake strongly. IS $_{\mathrm{S}}$ emissions, on the other hand, stayed high down to a SWP of $-3 \mathrm{MPa}$ and then decreased gradually. We consider that leaves must have maintained a high production of IS to sustain similar emissions compared to a SWP of $-2 \mathrm{MPa}$. $\mathrm{MT}_{\mathrm{S}}$ and $\mathrm{SQT}_{\mathrm{S}}$ emissions increased under high drought stress. Plants that were subject to $1 \mathrm{~h}$ of ozone fumigation $(\sim 100 \mathrm{ppbv})$ every day in addition to reduced watering showed lower stomatal conductance at mild drought stress compared to those with no ozone fumigation, and consecutively the effect of drought was slowed down. The shikimate pathway, producing antioxidants, was stimulated earlier in the set with ozone. The combination of (i) sustained isoprene emissions, (ii) increase in antioxidants due to the higher stimulation of the two pathways (phenylpropanoid and shikimate), and (iii) early closure of the stomata resulted in a longer endurance of drought stress in the set exposed to ozone. Therefore, we conclude that fumigation with moderately high ozone levels $(\sim 100 \mathrm{ppbv})$ decelerated the effect of drought in $Q$. robur. Overall $Q$. robur leaves appeared very resistant to drought stress. Consequently GLVs indicating cell damage were only emitted at SWP $<-5 \mathrm{MPa}$.
As seasonal drought events and elevated ozone concentrations often occur in parallel in midlatitudes (Löw et al., 2006; Panek et al., 2002), it is important to study their combined stress effects. In this study we observe that a combination of stresses can lead to opposing feedbacks that alter BVOC emissions. These effects are compound-specific and reflect biochemical changes in the plant. 


\section{Appendix A}

Table A1. Acronyms and experimental conditions used in this experiment.

\begin{tabular}{ll}
\hline ACRONYMS & \\
\hline$A$ & Net photosynthesis $\left(\mathrm{CO}_{2}\right.$ assimilation rate $)$ \\
BVOCs & Biogenetic volatile organic compounds \\
$C$ & Control samples without ozone treatment \\
$\mathrm{DS}$ & Set under drought stress without ozone treatment \\
$\mathrm{DS} \times$ OS & Set under drought stress with ozone treatment \\
$g_{\mathrm{S}}$ & Stomatal conductance \\
GLVs & Green leaf volatiles \\
$\mathrm{IS}$ & Isoprene \\
ISs & Standardized emissions of isoprene \\
MeSa & Methyl salicylate \\
MT & Sum of monoterpenes \\
MT & Standardized emissions of MT \\
$\mathrm{O}_{3}$ & Ozone \\
OS & Well-watered control samples with ozone treatment \\
PTR-Tof-MS & Proton-transfer-reaction time-of-flight mass spectrometer \\
$Q$. robur & Quercus robur $\mathrm{L}$. \\
ROS & Reactive oxygen species \\
SQT & Sum of sesquiterpenes \\
SQT & Standardized emissions of SQT \\
SD & Standard deviation \\
SWP & Stem water potential \\
TPhe & Total phenol content \\
\hline Experimental conditions & \\
\hline Enclosure pressure & $2.386 \mathrm{kPa}^{\circ}$ \\
Mean leaf temperature & $29.06^{\circ} \mathrm{C}$ \\
Mean PAR & $1374 \mu$ mol $\mathrm{m}^{-2} \mathrm{~s}^{-1}$ \\
Ozone concentration & 100 ppb \\
Standardized temperature & $30^{\circ} \mathrm{C}$ \\
Standardized PAR & $1000 \mu$ mol m ${ }^{-2} \mathrm{~s}^{-1}$ \\
\hline &
\end{tabular}

Table A2. The $m / z$ ratio and chemical formula and name of compounds present in the standard gas mixture used for the daily calibration of the PTR-Tof-MS

\begin{tabular}{lll}
\hline$m / z$ ratio & Chemical formula & Compound \\
\hline 32.0262 & $\mathrm{CH}_{3} \mathrm{OH}$ & Methanol \\
41.0265 & $\mathrm{C}_{2} \mathrm{H}_{3} \mathrm{~N}$ & Acetonitrile \\
44.0261 & $\mathrm{C}_{2} \mathrm{H}_{4} \mathrm{O}$ & Acetaldehyde \\
58.0418 & $\mathrm{C}_{3} \mathrm{H}_{6} \mathrm{O}$ & Acetone \\
72.0574 & $\mathrm{C}_{4} \mathrm{H}_{8} \mathrm{O}$ & Methyl ethyl ketone (MEK) \\
78.0469 & $\mathrm{C}_{6} \mathrm{H}_{6}$ & Benzene \\
92.0625 & $\mathrm{C}_{7} \mathrm{H}_{8}$ & Toluene \\
106.0782 & $\mathrm{C}_{8} \mathrm{H}_{10}$ & Xylenes \\
120.0939 & $\mathrm{C}_{9} \mathrm{H}_{12}$ & 1,2,4-Trimethylbenzene (TMB) \\
136.1252 & $\mathrm{C}_{10} \mathrm{H}_{16}$ & $a$-Pinene \\
62.0189 & $\mathrm{C}_{2} \mathrm{H}_{6} \mathrm{~S}$ & Dimethyl sulfide (DMS) \\
86.0731 & $\mathrm{C}_{5} \mathrm{H}_{10} \mathrm{O}$ & 2-Methyl-3-buten-2-ol (MBO) \\
134.1095 & $\mathrm{C}_{10} \mathrm{H}_{14}$ & 1,2,4,5-Tetramethylbenzene \\
\hline
\end{tabular}


Table A3. Measured $m / z$ ratio, chemical formula, and tentative assignment of compounds used for the calculation of the sum of BVOCs in $\mathrm{C}_{\mathrm{BVOCs}} / C_{\mathrm{A}}$.

\begin{tabular}{lll}
\hline$m / z$ ratio & $\mathrm{Chemical}$ formula & Compound \\
\hline 33.033 & $\left(\mathrm{CH}_{4} \mathrm{O}\right) \mathrm{H}^{+}$ & Methanol \\
45.033 & $\left(\mathrm{C}_{2} \mathrm{H}_{4} \mathrm{O}\right) \mathrm{H}^{+}$ & Acetaldehyde \\
47.049 & $\left(\mathrm{C}_{2} \mathrm{H}_{6} \mathrm{O}\right) \mathrm{H}^{+}$ & Ethanol \\
57.033 & $\left({\left.\mathrm{C} 3 \mathrm{H}_{4} \mathrm{O}\right) \mathrm{H}^{+}}^{+}\right.$ & E-2-Hexenal fragment \\
57.069 & $\left(\mathrm{C}_{4} \mathrm{H}_{8}\right) \mathrm{H}^{+}$ & Butyl \\
59.049 & $\left(\mathrm{C}_{3} \mathrm{H}_{6} \mathrm{O}\right) \mathrm{H}^{+}$ & Acetone \\
61.028 & $\left(\mathrm{C}_{2} \mathrm{H}_{4} \mathrm{O}_{2}\right) \mathrm{H}^{+}$ & Acetic acid \\
71.049 & $\left(\mathrm{C}_{4} \mathrm{H}_{6} \mathrm{O}\right) \mathrm{H}^{+}$ & Methyl vinyl ketone (MVK)/methacrolein (MAC) \\
73.064 & $\left(\mathrm{C}_{4} \mathrm{H}_{8} \mathrm{O}\right) \mathrm{H}^{+}$ & Methyl ethyl ketone (MEK) \\
79.054 & $\left(\mathrm{C}_{6} \mathrm{H}_{6}\right) \mathrm{H}^{+}$ & Benzene \\
83.085 & $\left(\mathrm{C}_{6} \mathrm{H}_{10}\right) \mathrm{H}^{+}$ & Hexanals/hexenol fragment \\
85.101 & $\left(\mathrm{C}_{6} \mathrm{H}_{2}\right) \mathrm{H}^{+}$ & Hexene \\
87.080 & $\left(\mathrm{C}_{5} \mathrm{H}_{10} \mathrm{O}\right) \mathrm{H}^{+}$ & 2-Methyl-3-buten-2-ol (MBO) \\
93.069 & $\left(\mathrm{C}_{7} \mathrm{H}_{8}\right) \mathrm{H}^{+}$ & Toluene/MT fragment \\
95.050 & $\left(\mathrm{C}_{6} \mathrm{H}_{5} \mathrm{OH}\right) \mathrm{H}^{+}$ & Phenol \\
99.080 & $\left(\mathrm{C}_{6} \mathrm{H}_{10} \mathrm{O}\right) \mathrm{H}^{+}$ & Hexenals \\
101.096 & $\left(\mathrm{C}_{6} \mathrm{H}_{2} \mathrm{O}\right) \mathrm{H}^{+}$ & Hexanal \\
107.049 & $\left(\mathrm{C}_{7} \mathrm{H}_{6} \mathrm{O}\right) \mathrm{H}^{+}$ & Benzaldehyde \\
107.073 & $\left(\mathrm{C}_{8} \mathrm{H}_{10}\right) \mathrm{H}^{+}$ & Xylenes \\
143.107 & $\left(\mathrm{C}_{8} \mathrm{H}_{14} \mathrm{O}_{2}\right) \mathrm{H}^{+}$ & Hexenylacetate \\
145.122 & $\left(\mathrm{C}_{8} \mathrm{H}_{16} \mathrm{O}_{2}\right) \mathrm{H}^{+}$ & Hexylacetate \\
153.055 & $\left(\mathrm{C}_{8} \mathrm{H}_{8} \mathrm{O}_{3}\right) \mathrm{H}^{+}$ & Methyl salicylate (MeSa) \\
165.092 & $\left(\mathrm{C}_{10} \mathrm{H}_{12} \mathrm{O}_{2}\right) \mathrm{H}^{+}$ & Eugenol \\
211.133 & $\left(\mathrm{C}_{12} \mathrm{H}_{18} \mathrm{O}_{3}\right) \mathrm{H}^{+}$ & Jasmonic acid \\
225.149 & $\left(\mathrm{C}_{12} \mathrm{H}_{20} \mathrm{O}_{3}\right) \mathrm{H}^{+}$ & Methyl jasmonate \\
265.144 & $\left(\mathrm{C}_{15} \mathrm{H}_{20} \mathrm{O}_{4}\right) \mathrm{H}^{+}$ & Abscisic acid (ABA) \\
69.070 & $\left(\mathrm{C}_{5} \mathrm{H}_{8}\right) \mathrm{H}^{+}$ & Isoprene (IS) \\
137.133 & $\left(\mathrm{C}_{10} \mathrm{H}_{16}\right) \mathrm{H}^{+}$ & Monoterpenes (MT) \\
205.195 & $\left(\mathrm{C}_{15} \mathrm{H}_{24}\right) \mathrm{H}^{+}$ & Sesquiterpenes (SQT) \\
\hline & &
\end{tabular}

Table A4. Mean dry weight and mean specific leaf area for $20 \%$ of the total analyzed leaves of sets DS and DS $\times$ OS.

\begin{tabular}{lll}
\hline & Dry weight $[\mathrm{g}]$ & Specific leaf area $\left[\mathrm{m}^{2}\right]$ \\
\hline DS & 1.16 & 0.015 \\
DS $\times$ OS & 0.82 & 0.011 \\
\hline
\end{tabular}


Data availability. All data included in this study are available upon request via contact with the corresponding author, Thomas Karl (thomas.karl@uibk.ac.at).

Author contributions. AP, LK, TK, GW, and HH drafted the manuscript, which was edited by all co-authors. Laboratory work was performed by AP, LK, ACF, MG, TK, HS, and JG. AP, LK, $\mathrm{ACF}$, and $\mathrm{HH}$ analyzed and interpreted the data.

Competing interests. The authors declare that they have no conflict of interest.

Acknowledgements. This work was supported by the Vienna Science and Technology Fund (WWTF, project number ESR17-027). In addition Arianna Peron was supported by a doctoral grant fellowship of the LFU. We are grateful to Polona Jamnik for kindly providing Saccharomyces cerevisiae ZIM 2155 from the Culture Collection of Industrial Microrganisms (ZIM) of the Biotechnical Faculty of University of Ljubljana, Ljubljana, Slovenia. Support in the analysis of the leaves by Silvija Marinovic and Michael Kurta at TU Wien is also gratefully acknowledged. We would also like to thank Astrid Mach-Aigner (research group Synthetic Biology and Molecular Biotechnology at the Institute of Chemical, Environmental and Bioscience Engineering, TU Wien) for kindly offering access to the GloMax ${ }^{\circledR}$ Multi Microplate Reader.

Financial support. This research has been supported by the WWTF (grant no. ESR17-027) and partially by FWF (grant no. P30600).

Review statement. This paper was edited by Dan Yakir and reviewed by Ana Maria Yañez-Serrano and one anonymous referee.

\section{References}

Affek, H. P. and Yakir, D.: Protection by isoprene against singlet oxygen in leaves, Plant Physiol., 129, 269-277, https://doi.org/10.1104/pp.010909, 2002.

Affek, H. P. and Yakir, D.: Natural abundance carbon isotopes composition of isoprene reflects incomplete coupling between isoprene synthesis and photosynthesis carbon flow, Plant Physiol. 131, 1727-1736, https://doi.org/10.1104/pp.102.012294, 2003.

Allen, C. D., Macalady, A., Chenchouni, H., Bachelet, D., McDowell, N., Vennetier, M., Kitzberger, T., Gonzales, P., Hogg, T., Rigling, A., Breshears, D., Gonzalez, P., Fensham, R., Zhang, Z., Castro, J., Demidova, N., Lim, J. H., Allard, G., Running, S. W., Semerci, A., and Cobb, N.: A global overview of drought and heat-induced tree mortalityreveals emerging climate change risks for forests, Forest Ecol. Manag., 259, 660-684, https://doi.org/10.1016/j.foreco.2009.09.001, 2010.

Amin, H. S., Atkins, P. T., Russo, R., Brown, A. W., Sive, B., Hallar, A. G., and Huff Hartz, K. E.: Effect of bark beetle infestation on secondary organic aerosol precursor emissions, Environ. Sci.
Technol., 46, 5696-5703, https://doi.org/10.1021/es204205m, 2012.

Amin, H. S., Russo, R. S., Sive, B., Hoebeke, E. R., Dodson, C., McCubbin I. B., Hallar, A. G., and Huff Hartz, K. E.: Monoterpene emissions from bark beetle infested Engelmann spruce trees, Atmos. Environ., 72, 130-133, https://doi.org/10.1016/j.atmosenv.2013.02.025, 2013.

Atkinson, R. and Arey, J.: Gas-phase tropospheric chemistry of biogenic volatile organic compounds: a review, Atmos. Environ., 37, 197-219, https://doi.org/10.1016/S1352-2310(03)00391-1, 2003.

Baier, M., Kandlbinder, A., Golldack, D., and Dietz, K. J.: Oxidative stress and ozone: perception, signaling and response, Plant Cell Environ., 28, 1012-1020, https://doi.org/10.1111/j.13653040.2005.01326.x, 2005.

Baldocchi, D., Guenther, A. B., Harley, P. C., Klinger, L., Zimmerman, P., Lamb, B., and Westberg, H.: The fluxes and air chemistry of isoprene above a deciduous hardwood forest, Philos. T. R. Soc. A., 351, 279-296, https://doi.org/10.1098/rsta.1995.0034, 1995.

Baldwin, I. T., Halitschke, R., Paschold, A., von Dahl, C. C., and Preston, C. A.: Volatile signaling in plant-plant interactions: "Talking trees" in the genomics era, Science, 311, 812-815, https://doi.org/10.1126/science.1118446, 2006.

Barstow, M. and Khela, S.: Quercus robur. The IUCN Red List of Threatened Species 2017: e.T63532A3126467, available at: https://www.iucnredlist.org/species/63532/3126467 (last access: 15 August 2020), 2017.

Beauchamp, J., Wisthaler, A., Hansel, A., Kleist, E., Miebach, M., Niinemets, Ü., and Wildt, J.: Ozone induced emissions of biogenic VOC from tobacco: relationships between ozone uptake and emission of LOX products, Plant Cell Environ., 28, 1334 1343, https://doi.org/10.1111/j.1365-3040.2005.01383.x, 2005.

Beckett, M., Loreto, F., Velikova, V., Brunetti, C., Di Ferdinando, M., Tattini, M., and Farrant, J. M.: Photosynthetic limitations and volatile and non-volatile isoprenoids in the poikilochlorophyllous resurrection plant Xerophyta humilis during dehydration and rehydration, Plant Cell Environ., 35, 2061-2074, https://doi.org/10.1111/j.1365-3040.2012.02536.x, 2012.

Behnke, K., Kleist, E., Uerlings, R., Wildt, J., Rennenberg, H., and Schnitzler, J. P.: RNAi-mediated suppression of isoprene biosynthesis in hybrid poplar impacts ozone tolerance, Tree Physiol., 29, 725-736, https://doi.org/10.1093/treephys/tpp009, 2009.

Benjamin, M. T. and Winer, A. M.: Estimating the ozone-forming potential of urban trees and shrubs, Atmos. Environ., 32, 53-68, https://doi.org/10.1016/S1352-2310(97)00176-3, 1998.

Bentley, R., and Haslam, E.: The Shikimate Pathway - A Metabolic Tree with Many Branche, Crit. Rev. Biochem. Mol., 25, 307384, https://doi.org/10.3109/10409239009090615, 2008.

Berg, A. R., Heald, C. L., Huff Hartz, K. E., Hallar, A. G., Meddens, A. J. H., Hicke, J. A., Lamarque, J.-F., and Tilmes, S.: The impact of bark beetle infestations on monoterpene emissions and secondary organic aerosol formation in western North America, Atmos. Chem. Phys., 13, 3149-3161, https://doi.org/10.5194/acp13-3149-2013, 2013.

Betz, G. A., Knappe, C., Lapierre, C., Olbrich, M., Welzl, G., Langebartels, C., Heller, W., Sandermann, H., and Ernst, D.: Ozone affects shikimate pathway transcripts and monomeric lignin composition in European beech (Fagus sylvatica L.), Eur. 
J. Forest Res., 128, 109-116, https://doi.org/10.1007/s10342008-0216-8, 2009.

Bourtsoukidis, E., Bonn, B., Dittmann, A., Hakola, H., Hellén, H., and Jacobi, S.: Ozone stress as a driving force of sesquiterpene emissions: a suggested parameterisation, Biogeosciences, 9, 4337-4352, https://doi.org/10.5194/bg-9-4337-2012, 2012.

Bowen, I. S.: The ratio of heat losses by conduction and by evaporation from any water surface, Phys. Rev. E., 27, 779-787, https://doi.org/10.1103/PhysRev.27.779, 1926.

Brilli, F., Barta, C., Fortunati, A., Lerdau, M., Loreto, F., and Centritto, M.: Response of isoprene emission and carbon metabolism to drought in white poplar (Populus alba) saplings, New Phytol., 175, 244-254, https://doi.org/10.1111/j.14698137.2007.02094.x, 2007.

Brilli, F., Ruuskanen, T. M., Schnitzhofer, R., Müller, M., Breitenlechner, M., Bittner, V., and Hansel, A.: Detection of plant volatiles after leaf wounding and darkening by Proton Transfer Reaction "Time-of-Flight" Mass Spectrometry (PTR-TOF), PloS One, 6, e20419, https://doi.org/10.1371/journal.pone.0020419, 2011.

Brilli, F., Gioli, B., Fares, S., Terenzio, Z., Zona, D., Gielen, B., and Ceulemans, R.: Rapid leaf development drives the seasonal pattern of volatile organic compound (VOC) fluxes in a "coppiced" bioenergy poplar plantation, Plant Cell Environ., 39, 539-555, https://doi.org/10.1111/pce.12638, 2016.

Brüggemann, N. and Schnitzler, J. P.: Comparison of isoprene emission, intercellular isoprene concentration and photosynthetic performance in water-limited oak (Quercus pubescens Willd. and Quercus robur L.) saplings, Plant Biol., 4, 456-463, https://doi.org/10.1055/s-2002-34128, 2002.

Cabané, M., Pireaux, J. C., Leger, E., Weber, E., Dizengremel, P., Pollet, B., and Lapierre, C.: Condensed lignins are synthesized in poplar leaves exposed to ozone, Plant Physiol., 134, 586-594, https://doi.org/10.1104/pp.103.031765, 2004.

Cappellin, L., Karl, T., Probst, M., Ismailova, O., Winkler, P. M., Soukoulis, C., Aprea, E., Märk, T. D., Gasperi, F., and Biasioli, F.: On Quantitative Determination of Volatile Organic Compound Concentrations Using Proton Transfer Reaction Time-ofFlight Mass Spectrometry, Environ. Sci. Technol., 46, 22832290, https://doi.org/10.1021/es203985t, 2012.

Chaves, M. M., Maroco, J. P., and Pereira, J. S.: Understanding plant responses to drought: from genes to the whole plant, Funct. Plant Biol., 30, 239-264, https://doi.org/10.1071/FP02076, 2003.

Cheng, A. X., Lou, Y. G., Mao, Y. B., Lu, S., Wang, L. J., and Chen, X. Y.: Plant terpenoids: biosynthesis and ecological functions, J. Integr. Plant Biol., 49, 179-186, https://doi.org/10.1111/j.17447909.2007.00395.x, 2007.

CIRAS-3 Operation Manual V. 2-01, PP-Systems, Amesbury, MA, USA, available at: http://ppsystems.com>80097-1-CIRAS3_ Operation_V200 (last access: 6 July 2020), 2018.

Claeys, M., Wang, W., Ion, A. C., Kourtchev, I., Gelencsér, A., and Maenhaut, W.: Formation of secondary organic aerosols from isoprene and its gas-phase oxidation products through reaction with hydrogen peroxide, Atmos. Environ., 38, 4093-4098, https://doi.org/10.1016/j.atmosenv.2004.06.001, 2004.

Cotrozzi, L., Remorini, D., Pellegrini, E., Guidi, L., Lorenzini, G., Massai, R., Nali, C., and Landi, M.: Cross-talk between physiological and metabolic adjustments adopted by Quercus cerris to mitigate the effects of severe drought and realistic future ozone concentrations, Forests, 8, 148, https://doi.org/10.3390/f8050148, 2017.

Croft, K. P. C., Jüttner, F., and Slusarenko, A. J.: Volatile products of the lipoxygenase pathway evolved from Phaseolus vulgaris $\mathrm{L}$. leaves inoculated with Pseudomonas syringae pv. phaseolicola, Plant Physiol., 101, 13-24, https://doi.org/10.1104/pp.101.1.13, 1993.

Dai, A.: Increasing drought under global warming in observations and models, Nat. Clim. Change, 3, 52-58, https://doi.org/10.1038/nclimate1633, 2013.

Dixon, R. A. and Paiva, N. L.: Stress-induced phenylpropanoid metabolism, Plant Cell, 7, 1085-1097, https://doi.org/10.1105/tpc.7.7.1085, 1995.

Ebel, R. C., Mattheis, J. P., and Buchanan, D. A.: Drought stress of apple trees alters leaf emissions of volatile compounds, Physiol. Plantarum, 93, 709-712, https://doi.org/10.1111/j.13993054.1995.tb05120.x, 1995.

EEA: Air quality in Europe - 2017 report, EEA Report No. 17/20217, European Environment Agency, Copenhagen, available at: https://www.eea.europa.eu/publications/ air-quality-in-europe-2017 (last access: 6 July 2020), 2017.

EFDAC: Species Distribution, European Forest Data Centre, available at: https://ies-ows.jrc.ec.europa.eu/efdac/download/Atlas/ pdf/European_forests_an_ecological_overview.pdf (last access: 6 July 2020), 2015.

Ellenberg, H. H.: Vegetation ecology of central Europe, 4th edition, Cambridge University Press, Cambridge, UK, 756 pp., ISBN 9780521115124, 1988.

Fall, R., Karl, T., Hansel, A., Jordan, A., and Lindinger, W.: Volatile organic compounds emitted after leaf wounding: On-line analysis by proton-transfer-reaction mass spectrometry, J. Geophys. Res., 104, 15963-15974, https://doi.org/10.1029/1999JD900144, 1999.

Fang, C., Monson, R. K., and Cowling, E. B.: Isoprene emission, photosynthesis, and growth in sweetgum (Liquidambar styraciflua) seedlings exposed to short- and long-term drying cycles, Tree Physiol., 16, 441-446, https://doi.org/10.1093/treephys/16.4.441, 1996.

Farage, P., Long, S., Lechner, E., and Baker, N.: The sequence of change within the photosynthetic apparatus of wheat following short-term exposure to ozone, Plant Physiol., 95, 529-535, https://doi.org/10.1104/pp.95.2.529, 1991.

Fares, S., Barta, C., Brilli, F., Centritto, M., Ederli, L., Ferranti, F., Pasqualini, S., Reale, L., Tricoli, D., and Loreto, F.: Impact of high ozone on isoprene emission, photosynthesis and histology of developing Populus alba leaves directly or indirectly exposed to the pollutant, Physiol. Plantarum, 128, 456465, https://doi.org/10.1111/j.1399-3054.2006.00750.x, 2006.

Filella, I., Primante, C., Llusiá, J., Martín González, A. M., FarréArmengol, G., Rodrigo, A., Bosch, J., and Peñuelas, J.: Floral advertisement scent in a changing plant-pollinators market, Sci. Rep.-UK., 3, 3434, doi.org/10.1038/srep03434, 2013.

Fitzky, A. C., Sandén, H., Karl, T., Fares, S., Calfapietra, C., Grote, R., Saunier, A., and Rewald, B.: The interplay between ozone and urban vegetation BVOC emissions, ozone deposition, and tree ecophysiology, Front. For. Glob. Change, 2, p. 50, https://doi.org/10.3389/ffgc.2019.00050, 2019.

Funk, J. L., Mak, J. E., and Lerdau, M. T.: Stress-induced changes in carbon sources for isoprene production in Populus deltoids, 
Plant Cell Environ., 27, 747-755, https://doi.org/10.1111/j.13653040.2004.01177.x, 2004.

Geron, C., Guenther, A., and Pierce, T.: An improved model for estimating emissions of volatile organic compounds from forests in the eastern United States, J. Geophys. Res., 99, 12773-12791, https://doi.org/10.1029/94JD00246, 1994.

Giacomuzzi, V., Cappellin, L., Khomenko, I., Biasioli, F., Schütz, S., Tasin, M., Knight, A. L., and Angeli, S.: Emission of volatile compounds from apple plants infested with Pandemis heparana larvae, antennal response of conspecific adults, and preliminary field trial, J. Chem. Ecol., 42, 1265-1280, https://doi.org/10.1007/s10886-016-0794-8, 2016.

Graus, M., Müller, M., and Hansel, A.: High resolution PTR-TOF: quantification and formula confirmation of VOC in real time, J. Am. Soc. Mass Spectr., 21, 1037-1044, https://doi.org/10.1016/j.jasms.2010.02.006, 2010.

Griffin, R. J., Cocker III, D. R., Flagan, R. C., and Seinfeld, J. H.: Organic aerosol formation from oxidation of biogenic hydrocarbons, J. Geophys. Res.-Atmos., 104, 3555-3567, https://doi.org/10.1029/1998JD100049, 1999.

Guenther, A. B., Zimmerman, P. R., Harley, P. C., Monson, R. K., and Fall, R.: Isoprene and monoterpene emission rate variability: Model evaluation and sensitivity analysis, J. Geophys. Res., 98, 609-617, https://doi.org/10.1029/93JD00527, 1993.

Guenther, A. B., Hewitt, C. N., Erickson, D., Fall, R., Geron, C., Graedel, T., Harley, P., Klinger, L., Lerdau, M., McKay, W. A., Pierce, T., Scholes, B., Steinbrecher, R., Tallamraju, R., Taylor, J., and Zimmermann, P.: A global model of natural volatile organic compounds emissions, J. Geophys. Res., 100, 8873-8892, https://doi.org/10.1029/94JD02950, 1995.

Guenther, A. B., Jiang, X., Heald, C. L., Sakulyanontvittaya, T., Duhl, T., Emmons, L. K., and Wang, X.: The Model of Emissions of Gases and Aerosols from Nature version 2.1 (MEGAN2.1): an extended and updated framework for modeling biogenic emissions, Geosci. Model Dev., 5, 1471-1492, https://doi.org/10.5194/gmd-5-1471-2012, 2012.

Hallquist, M., Wenger, J. C., Baltensperger, U., Rudich, Y., Simpson, D., Claeys, M., Dommen, J., Donahue, N. M., George, C., Goldstein, A. H., Hamilton, J. F., Herrmann, H., Hoffmann, T., Iinuma, Y., Jang, M., Jenkin, M. E., Jimenez, J. L., Kiendler-Scharr, A., Maenhaut, W., McFiggans, G., Mentel, Th. F., Monod, A., Prévôt, A. S. H., Seinfeld, J. H., Surratt, J. D., Szmigielski, R., and Wildt, J.: The formation, properties and impact of secondary organic aerosol: current and emerging issues, Atmos. Chem. Phys., 9, 5155-5236, https://doi.org/10.5194/acp9-5155-2009, 2009.

Hatanaka, A.: The biogeneration of green odor by green leaves, Phytochemistry, 34, 1201-1218, https://doi.org/10.1016/00319422(91)80003-J, 1993.

Heath, R. L.: Modification of the biochemical pathways of plants induced by ozone: what are the varied routs to change?, Environ. Pollut., 155, 453-463, https://doi.org/10.1016/j.envpol.2008.03.010, 2008.

Heiden, A. C., Hoffmann, T., Kahl, J., Kley, D., Klockow, D., Langebartels, C., Mehlhorn, H., Sandermann Jr., H., Schraudner, M., Schuh, G., and Wildt, J.: Emission of volatile organic compounds from ozone-exposed plants, Ecol. Appl., 19, 1160-1167, https://doi.org/10.1890/10510761(1999)009[1160:EOVOCF]2.0.CO;2, 1999.
Heiden, A. C., Kobel, K., Langebartels, C., Schuh-Thomas, G., and Wildt, J.: Emissions of oxygenated volatile organic compounds from plants, part I: Emissions from lipoxygenase activity, J. Atmos. Chem., 45, 143-172, https://doi.org/10.1023/A:1024069605420, 2003.

Herrmann, K. M. and Weaver, L. M.: The shikimate pathway, Annu. Rev. Plant Phys., 50, 473-503, https://doi.org/10.1146/annurev.arplant.50.1.473, 1999.

Hollaway, M. J., Arnold, S. R., Challinor, A. J., and Emberson, L. D.: Intercontinental trans-boundary contributions to ozone-induced crop yield losses in the Northern Hemisphere, Biogeosciences, 9, 271-292, https://doi.org/10.5194/bg-9-2712012, 2012.

Ibrahim, M. A., Nissinen, A., Prozherina, N., Oksanen, E. J., and Holopainen, J. K.: The influence of exogenous monoterpene treatment and elevated temperature on growth, physiology, chemical content and headspace volatiles of 2 carrot cultivars (Daucus carota L.), Environ. Exp. Bot., 56, 95-107, https://doi.org/10.1016/j.envexpbot.2005.01.006, 2006.

IPCC: Solomon, S., Qin, D., Manning, M., Chen, Z., Marquis, M., Averyt, K. B., Tignor, M., and Miller, H. L.: Climate Change 2007: The Physical Science Basis. Contribution of Working Group I to the Fourth Assessment Report of the Intergovernmental Panel on Climate Change, Cambridge University Press, Cambridge, UK, and New York, 1007 pp., 2007.

Jolivet, Y., Bagard, M., Cabané, M., Vaultier, M. N., Gandin, A., Afif, D., Dizengremel P., and Le Thiec, D.: Deciphering the ozone-induced changes in cellular processes: a prerequisite for ozone risk assessment at the tree and forest levels, Ann. For. Sci., 73, 923-943, https://doi.org/10.1007/s13595-016-0580-3, 2016.

Jonsson, L.: Impacts of climate change on pedunculate oak (Quercus robur L.) and Phytophthora activity in north and central Europe, Department of Physical Geography and Ecosystem Science, Lund University, Lund, Sweden, available at: https:// lup.lub.lu.se/student-papers/search/publication/2970623 (last access: 15 August 2020), 2012.

Kanagendran, A., Pazouki, L., and Niinemets, Ü.: Differential regulation of volatile emission from Eucalyptus globulus leaves upon single and combined ozone and wounding treatments through recovery and relationships with ozone uptake, Environ. Exp. Bot., 145, 21-38, https://doi.org/10.1016/j.envexpbot.2017.10.012, 2018.

Kangasjärvi, J., Talvinen, L., Utriainen, M., and Karjalainen, R.: Plant defence systems induced by ozone, Plant Cell Environ., 17, 783-794, https://doi.org/10.1111/j.1365-3040.1994.tb00173.x, 1994.

Karl, M., Guenther, A., Köble, R., Leip, A., and Seufert, G.: A new European plant-specific emission inventory of biogenic volatile organic compounds for use in atmospheric transport models, Biogeosciences, 6, 1059-1087, https://doi.org/10.5194/bg-6-10592009, 2009.

Karl, T., Guenther, A., Lindinger, C., Jordan, A., Fall, R., and Lindinger, W.: Eddy covariance measurements of oxygenated volatile organic compound fluxes from crop harvesting using a redesigned proton-transfer-reaction mass spectrometer, J. Geophys. Res., 106, 24157-24167, https://doi.org/10.1029/2000JD000112, 2001.

Karl, T., Fall, R., Rosentiel, T. N., Prazeller, P., Larsen, B., Seufert, G., and Lindinger, W.: On-line analysis of the 
${ }^{13} \mathrm{CO}_{2}$ labeling of leaf isoprene suggests multiple subcellular origins of isoprene precursors, Planta, 215, 894-905, https://doi.org/10.1007/s00425-002-0825-2, 2002.

Karl, T., Harren, F., Warneke, C., de Gouw, J., Grayless, C., and Fall, R.: Senescing grass crops as regional sources of reactive volatile organic compounds, J. Geophys. Res., 110, D15302, https://doi.org/10.1029/2005JD005777, 2005.

Karl, T., Guenther, A., Turnipseed, A., Patton, E. G., and Jardine, K.: Chemical sensing of plant stress at the ecosystem scale, Biogeosciences, 5, 1287-1294, https://doi.org/10.5194/bg-5-12872008, 2008.

Kessler, A. and Balwin, I. T.: Defensive function of herbivoreinduced plant volatile emissions in nature, Science, 291, 21412144, https://doi.org/10.1126/science.291.5511.2141, 2001.

Khatamian, H., Adedipe, N. O., and Ormrod, D. P.: Soil-water aspects of ozone phytotoxicity in tomato plants, Plant Soil, 30, 531-541, https://doi.org/10.1007/BF00010693, 1973.

Kobayashi, K., Miller, J. E., Flagler, R. B., and Heck, W. W.: Model analysis of interactive effects of ozone and waterstress on the yield of soybean, Environ. Pollut., 82, 39-45, https://doi.org/10.1016/0269-7491(93)90160-P, 1993.

Kreuzwieser, J., Graus, M., Wisthaler, A., Hansel, A., Rennenberg, H., and Schnitzler, J. P.: Xylem-transported glucose as additional carbon source for leaf isoprene formation in Quercus robur, New Phytol., 156, 171-178, https://doi.org/10.1046/j.14698137.2002.00516.x, 2002.

Kulmala, M., Suni, T., Lehtinen, K. E. J., Dal Maso, M., Boy, M., Reissell, A., Rannik, Ü., Aalto, P., Keronen, P., Hakola, H., Bäck, J., Hoffmann, T., Vesala, T., and Hari, P.: A new feedback mechanism linking forests, aerosols, and climate, Atmos. Chem. Phys., 4, 557-562, https://doi.org/10.5194/acp-4-557-2004, 2004.

Lak, Z. A., Sandén, H., Mayer, M., Godbold, D. L., and Rewald, B.: Plasticity of Root Traits under Competition for a Nutrient-Rich Patch Depends on Tree Species and Possesses a Large Congruency between Intra- and Interspecific Situations, Forests, 11, 528, https://doi.org/10.3390/f11050528, 2020.

Lal, R.: World soils and the greenhouse effect, IGBP Newsletter, 37, 4-5, 1999.

Laothawornkitkul, J., Taylor, J. E., Paul, N. D., and Hewitt, C. $\mathrm{N}$.: Biogenic volatile organic compounds in the Earth system, New Phytol., 183, 27-51, https://doi.org/10.1111/j.14698137.2009.02859.x, 2009.

Lee, J. D., Lewis, A. C., Monks, P. S., Jacob, M., Hamilton, J. F., Hopkins, J. R., Watson, N. M., Saxton, J. E., Ennis, C., Carpenter, L. J., Carslaw, N., Fleming, Z., Bandy, B. J., Oram, D. E., Penkett, S. A., Slemr, J., Norton, E., Rickard, A. R., Whalley, L. K., Heard, D. E., Bloss, W. J., Gravestock, T., Smit, S. C., Stanton, J., Pilling, M. J., and Jenkin, M. E.: Ozone photochemistry and elevated isoprene during the UK heatwave of August 2003, Atmos. Environ., 40, 7598-7613, https://doi.org/10.1016/j.atmosenv.2006.06.057, 2006.

Lehning, A., Zimmer, I., Steinbrecher, R., Hauff, K., Briiggemann, N., and Schnitzler. J. P.: Isoprene synthase activity and its relation to isoprene emission in Quercus robur L. leaves, Plant Cell Environ., 22, 495-504, https://doi.org/10.1046/j.13653040.1999.00425.x, 2002.

Lichtenthaler, H. K.: The 1-deoxy-D-xylulose-5-phosphatepathway of isoprenoid biosynthesis in plants, Annu. Rev. Plant Phys., 50, 47-66, https://doi.org/10.1146/annurev.arplant.50.1.47, 1999.
Lichtenthaler, H. K., Schwendler, J., Disch, A., and Rohmer, M.: Biosynthesis of isoprenoids in higher plant chloroplasts proceedsvia a mevalonate-independent pathway, FEBS Lett., 400, 271-274, https://doi.org/10.1016/S0014-5793(96)01404-4, 1997.

Llusiá, J. and Peñuelas, J.: Changes in terpene content and emission in potted Mediterranean woody plants under severe drought, Can. J. Botany, 76, 1366-1373, https://doi.org/10.1139/b98-141, 1998.

Loreto, F. and Schnitzler, J. P.: Abiotic stresses and induced BVOC's, Trends Plant Sci., 15, 154-166, https://doi.org/10.1016/j.tplants.2009.12.006, 2010.

Loreto, F. and Velikova, V.: Isoprene produced by leaves protects the photosynthetic apparatus against ozone damage, quenches ozone products, and reduces lipid peroxidation of cellular membranes, Plant Physiol., 127, 1781-1787, https://doi.org/10.1104/pp.010497, 2001.

Loreto, F., Pinelli, P., Manes, F., and Kollist, H.: Impact of ozone on monoterpene emissions and evidence for an isoprene-like antioxidant action of monoterpenes emitted by Quercus ilex leaves, Tree Physiol., 24, 361-367, https://doi.org/10.1093/treephys/24.4.361, 2004.

Löw, M., Herbinger, K., Nunn, A. J., Häberle, K. H., Leuchner, M., Heerdt, C., Werner, C., Wipfler, P., Pretzsch, H., Tausz, M., and Matyssek, R.: Extraordinary drought of 2003 overrules ozone impact on adult beech trees (Fagus sylvatica), Trees, 20, 539548, https://doi.org/10.1007/s00468-006-0069-z, 2006.

Maes, K. and Debergh, P. C.: Volatiles emitted from in vitro grown tomato shoots during abiotic and biotic stress, Plant Cell Tiss. Org., 75, 73-78, https://doi.org/10.1023/A:1024650006740, 2003.

Maffei, M. E.: Sites of synthesis, biochemistry and functional role of plant volatiles, S. Afr. J. Bot., 76, 612-631, https://doi.org/10.1016/j.sajb.2010.03.003, 2010.

Mahmoud, S. S. and Croteau, R. B.: Strategies for transgenic manipulation of monoterpene biosynthesis in plants, Trends Plant Sci., 7, 366-373, https://doi.org/10.1016/S1360-1385(02)023038, 2002

Maja, M. M., Kasurinen, A., Yli-Pirilä, P., Joutsensaari, J., Klemola, T., Holopainen, T., and Holopainen, J.: Contrasting responses of silver birch VOC emissions to shortand long-term herbivory, Tree Physiol., 34, 241-252, https://doi.org/10.1093/treephys/tpt127, 2014.

Matsui, K.: Green leaf volatiles: hydroperoxide lyase pathway of oxylipin metabolism, Curr. Opin. Plant Biol., 9, 274-280, https://doi.org/10.1016/j.pbi.2006.03.002, 2006.

McDowell, N., Pockman, W. T., Allen, C. D., Breshears, D. D., Cobb, N., Kolb, T., Sperry, J., West, A., Williams, D., and Yepez, E. A.: Mechanisms of plant survival and mortality during drought: why do some plants survive while others succumb to drought?, New Phytol., 178, 719-739, https://doi.org/10.1111/j.1469-8137.2008.02436.x, 2008.

Miller, J. D., Arteca, R. N., and Pell, E. J.: Senescenceassociated gene expression during ozone-induced leaf senescence in Arabidopsis, Plant Physiol., 120, 1015-1024, https://doi.org/10.1104/pp.120.4.1015, 1999.

Misztal, P. K., Hewitt, C. N., Wildt, J., Blande, J. D., Eller, A. S. D., Fares, S., Gentner, D. R., Gilman, J. B., Graus, M., Greenberg, J., Guenther, A. B., Hansel, A., Harley, P., Huang, M., Jar- 
dine, K., Karl, T., Kaser, L., Keutsch, F. N., Kiendler-Scharr, A., Kleist, E., Lerner, B. M., Li, T., Mak, J., Nölscher, A. C., Schnitzhofer, R., Sinha, V., Thornton, B., Warneke, C., Wegener, F., Werner, C., Williams, J., Worton, D. R., Yassaa, N., and Goldstein, A. H.: Atmospheric benzenoid emissions from plants rival those from fossil fuels, Sci. Rep.-UK., 5, 12064, https://doi.org/10.1038/srep12064, 2015.

Monson, R. K. and Fall, R.: Isoprene emission from aspen leaves, Plant Physiol., 90, 267-274, https://doi.org/10.1104/pp.90.1.267, 1989.

Müller, J.-F., Stavrakou, T., Wallens, S., De Smedt, I., Van Roozendael, M., Potosnak, M. J., Rinne, J., Munger, B., Goldstein, A., and Guenther, A. B.: Global isoprene emissions estimated using MEGAN, ECMWF analyses and a detailed canopy environment model, Atmos. Chem. Phys., 8, 1329-1341, https://doi.org/10.5194/acp-8-1329-2008, 2008.

Müller, M., Mikoviny, T., Jud, W., D’Anna, B., and Wisthaler, A.: A new software tool for the analysis of high resolution PTR-TOF mass spectra, Chemometr. Intell. Lab., 127, 158-165, https://doi.org/10.1016/j.chemolab.2013.06.011, 2013.

Niinemets, Ü.: Mild versus severe stress and BVOC's: thresholds, priming and consequences, Trends Plant Sci., 15, 145-153, https://doi.org/10.1016/j.tplants.2009.11.008, 2010.

Niinemets, Ü., Loreto, F., and Reichstein, M.: Physiological and physicochemical controls on foliar volatile organic compound emissions, Trends Plant Sci., 9, 180-186, https://doi.org/10.1016/j.tplants.2004.02.006, 2004.

Orlando, J. J., Noziere, B., Tyndall, G. S., Orzechowska, G. E.,Paulson, S. E., and Rudich, Y.: Product studies of the $\mathrm{OH}$-and ozone-initiated oxidation of some monoterpenes, J. Geophys. Res., 105, 11561-11572, https://doi.org/10.1029/2000JD900005, 2000.

Ormeño, E., Mevy, J. P., Vila, B., Bousquet-Melou, A., Greff, S., Bonin, G., and Fernandez, C.: Water deficit stress induces different monoterpene and sesquiterpene emission changes in Mediterranean species. Relationship between terpene emissions and plant water potential, Chemosphere, 67, 276-284, https://doi.org/10.1016/j.chemosphere.2006.10.029, 2007.

Owen, S., Boissard, C., Street, R., Duckham, S., Csiky, O., and Hewitt, C.: Screening of 18 Mediterranean plant species for volatile organic compound emissions, Atmos. Environ., 31, 101-117, https://doi.org/10.1016/S1352-2310(97)00078-2, 1997.

Palmer-Young, E. C., Veit, D., Gershenzon, J., and Schuman, M. C.: The sesquiterpenes $(e)-\beta$-farnesene and $(e)$ - $\alpha$-bergamotene quench ozone but fail to protect the wild tobacco nicotiana attenuata from ozone, UVB, and drought stresses, PLoS One, 10, e0127296, https://doi.org/10.1371/journal.pone.0127296, 2015.

Panek, J. A., Kurpius, M. R., and Goldstein, A. H.: An evaluation of ozone exposure metrics for a seasonally droughtstressed ponderosa pine ecosystem, Environ. Pollut., 117, 93100, https://doi.org/10.1016/S0269-7491(01)00155-5, 2002.

Paoletti, E.: Ozone slows stomatal response to light and leaf wounding in a Mediterranean evergreen broadleaf, Arbutus unedo, Environ. Poll., 134, 439-445, https://doi.org/10.1016/j.envpol.2004.09.011, 2005.

Paulot, F., Crounse, J. D., Kjaergaard, H. G., Kürten, A., St Clair, J. M., Seinfeld, J. H., and Wennberg, P. O.: Unexpected epoxide formation in the gas-phase photooxidation of isoprene, Science, 325, 730-733, https://doi.org/10.1126/science.1172910, 2009.
Pegoraro, E., Rey, A., Greenberg, J., Harley, P., Grace, J., Malhi, Y., and Guenther, A.: Effect of drought on isoprene emission rates from leaves of Quercus virginiana Mill, Atmos. Environ., 38, 6149-6156, https://doi.org/10.1016/j.atmosenv.2004.07.028, 2004.

Pellegrini, E., Hoshika, Y., Dusart, N., Cotrozzi, L., Gérard, J., Nali, C., Vaultier, M.-N., Jolivet, Y., Lorenzini, G., and Paoletti, E.: Antioxidative responses of 3 oak species under ozone and water stress conditions, Sci. Total Environ., 647, 390-399, https://doi.org/10.1016/j.scitotenv.2018.07.413, 2019.

Peñuelas, J. and Llusiá, J.: The complexity of factors driving volatile organic compound emissions by plants, Biol. Plantarum, 44, 481-487, https://doi.org/10.1023/A:1013797129428, 2001.

Peñuelas, J. and Llusiá, J.: BVOC's: plant defense against climate warming?, Trends Plant Sci., 8, 105-109, https://doi.org/10.1016/S1360-1385(03)00008-6, 2003.

Peñuelas, J. and Llusiá, J.: Plant VOC emissions: making use of the unavoidable, Trends Ecol. Evol., 19, 402-404, https://doi.org/10.1016/j.tree.2004.06.002, 2004.

Peñuelas, J. and Munné-Bosch, S.: Isoprenoids: an evolutionary pool for photoprotection, Trends Plant Sci., 10, 166-169, https://doi.org/10.1016/j.tplants.2005.02.005, 2005.

Peñuelas, J., Llusiá, J., and Gimeno, B. S.: Effects of ozone concentrations on biogenic volatile organic compounds emission in the Mediterranean region, Environ. Pollut., 105, 17-23, https://doi.org/10.1016/S0269-7491(98)00214-0, 1999.

Pinheiro, C. and Chaves, M. M.: Photosynthesis and drought: can we make metabolic connections from available data?, J. Exp. Bot., 62, 869-882, https://doi.org/10.1093/jxb/erq340, 2011.

Pollastrini, M., Desotgiu, R., Camin, F., Ziller, L., Gerosa, G., Marzuoli, R., and Bussotti, F.: Severe drought events increase the sensitivity to ozone on poplar clones, Environ. Exp. Bot., 100, 94-104, https://doi.org/10.1016/j.envexpbot.2013.12.016, 2014.

Portillo-Estrada, M., Kazantsev, T., and Niinemets, Ü.: Fading of wound-induced volatile release during Populus tremula leaf expansion, J. Plant Res., 130, 157-165, https://doi.org/10.1007/s10265-016-0880-6, 2017.

Rosenstiel, T., Potosnak, M., Griffin, K., Falle, R., and Monson, R. K.: Increased $\mathrm{CO}_{2}$ uncouples growth from isoprene emission in an agriforest ecosystem, Nature, 421, 256-259, https://doi.org/10.1038/nature01312, 2003.

Royal Society: Ground-level ozone in the 21st century: future trends, impacts and policy implications, Royal Society Science Policy Report, p. 15, The Royal Society, London, UK, 2008.

Ruzicka, L.: The isoprene rule and the biogenesis of terpenic compounds, Experientia, 9, 357-367, https://doi.org/10.1007/BF02167631, 1953.

Sandermann, H. and Strominger, J. L.: Purification and properties of C55-isoprenoid alcohol phosphokinase from Staphylococcus aureus, J. Biol. Chem., 247, 5123-5131, 1972.

Schaub, M., Haeni, M., Calatayud, V., Ferretti, M., and Gottardini, E.: Ozone concentrations are decreasing but exposure remains high in European forests, ICP Forests, 3, 6 pp., https://doi.org/10.3220/ICP1525258743000, 2018.

Schnitzler, J. P., Graus, M., Kreuzwieser, J., Heizmann, U., Rennenberg, H., Wisthaler, A., and Hansel, A.: Contribution of Different Carbon Sources to Isoprene Biosynthesis in Poplar Leaves, Plant Physiol., 135, 152-160, https://doi.org/10.1104/pp.103.037374, 2004. 
Schwanz, P. and Polle, A.: Differential stress responses of antioxidative systems to drought in pendunculate oak (Quercus robur) and maritime pine (Pinus pinaster) grown under high $\mathrm{CO}_{2}$ concentrations, J. Exp. Bot., 52, 133-143, https://doi.org/10.1093/jexbot/52.354.133, 2001.

Schwender, J., Zeidler, J., Gröner, R., Müller, C., Frocke, M., Braun, S., Lichtenthaler, F. W., and Lichtenthaler, H. K.: Incorporation of 1-deoxy-D-xylulose into isoprene and phytol by higher plants and algae, FEBS Lett., 414, 129-134, https://doi.org/10.1016/S0014-5793(97)01002-8, 1997.

Seco, R., Karl, T., Guenther, A., Hosman, K. P., Pallardy, S. G., Gu, L., Geron, C., Harley, P., and Kim, S.: Ecosystemscale volatile organic compound fluxes during an extreme drought in a broadleaf temperate forest of the Missouri Ozarks (central USA), Global Change Biol., 21, 3657-3674, https://doi.org/10.1111/gcb.12980, 2015.

Sharkey, T. D. and Loreto, F.: Water stress, temperature and light effects on the capacity for isoprene emission and photo-synthesis of kudzu leaves, Oecologia, 95, 328-333, https://doi.org/10.1007/BF00320984, 1993.

Sharkey, T. D., Loreto, F., and Delwiche, C. F.: High carbon dioxide and sun/shade effects on isoprene emission from oak and aspen tree leaves, Plant Cell Environ., 14, 333-338, https://doi.org/10.1111/j.1365-3040.1991.tb01509.x, 1991.

Siddique, M. R. B., Hamid, A. I. M. S., and Islam, M. S.: Drought stress effects on water relations of wheat, Bot. Bull. Acad. Sinica, 41, 35-39, https://doi.org/10.7016/BBAS.200001.0035, 2000.

Silver, G. M. and Fall, R.: Enzymatic synthesis of isoprene from dimethylallyl diphosphate in aspen leaf extracts, Plant Physiol., 97, 1588-1591, https://doi.org/10.1104/pp.97.4.1588, 1991.

Sindelarova, K., Granier, C., Bouarar, I., Guenther, A., Tilmes, S., Stavrakou, T., Müller, J.-F., Kuhn, U., Stefani, P., and Knorr, W.: Global data set of biogenic VOC emissions calculated by the MEGAN model over the last 30 years, Atmos. Chem. Phys., 14, 9317-9341, https://doi.org/10.5194/acp-14-9317-2014, 2014.

Singsaas, E. L., Lerdau, M., Winter, K., and Sharkey, T. D.: Isoprene increases thermotolerance of isopreneemitting species, Plant Physiol., 115, 1413-1420, https://doi.org/10.1104/pp.115.4.1413, 1997.

Slatnar, A., Jakopic, J., Stampar, F., Veberic, R., and Jamnik, P.: The effect of bioactive compounds on in vitro and in vivo antioxidant activity of different berry juices, PLoS One, 7, e47880, https://doi.org/10.1371/journal.pone.0047880, 2012.

Steinbrecher, R., Smiatek, G., Köble, R., Seufert, G., Theloke, J., Hauff, K., Ciccioli, P., Vautard, R., and Curci, G.: Intra-and inter-annual variability of VOC emissions from natural and semi-natural vegetation in Europe and neighboring countries, Atmos. Environ., 43, 1380-1391, https://doi.org/10.1016/j.atmosenv.2008.09.072, 2009.

Tasin, M., Cappellin, L., and Biasioli, F.: Fast direct injection mass-spectrometric characterization of stimuli for insect electrophysiology by proton transfer reaction-time of flight mass-spectrometry (PTR-ToF-MS), Sensors, 12, 4091-4104, https://doi.org/10.3390/s120404091, 2012.

Tingey, D.: The effect of environmental factors on the emission of biogenic hydrocarbons from live oak and slash pine, edited by: Bufalini, J. and Arnts, R., Atmospheric Biogenic Hydrocarbons, Butterworth, Stoneham, MA, USA, 53-72, 1981.
Tingey, D., Evans, R., and Gumpertz, M.: Effects of environmental conditions on isoprene emission from live oak, Planta, 152, 565570, https://doi.org/10.1007/BF00380829, 1981.

Tjoelker, M. G., Volin, J. C., Oleksyn, J., and Reich, P. B.: Interaction of ozone pollution and light effects on photosynthesis in a forest canopy experiment, Plant Cell Environ., 18, 895-905, https://doi.org/10.1111/j.1365-3040.1995.tb00598.x, 1995.

Toome, M., Randjärv, P., Copolovici, L. Niinemets, Ü., Heinsoo, K., Luik, A., and Steffen, M. N.: Leaf rust induced volatile organic compounds signalling in willow during the infection, Planta, 232, 235-243, https://doi.org/10.1007/s00425-010-1169-y, 2010.

Umlauf, D., Zapp, J., Becker, H., and Adam, K. P.: Biosynthesis of the irregular monoterpene artemisia ketone, the sesquiterpene germacrene $D$ and other isoprenoids in Tanacetum vulgare L. (Asteraceae), Phytochemistry, 65, 2463-2470, https://doi.org/10.1016/j.phytochem.2004.08.019, 2004.

Unger, N., Harper, K., Zheng, Y., Kiang, N. Y., Aleinov, I., Arneth, A., Schurgers, G., Amelynck, C., Goldstein, A., Guenther, A., Heinesch, B., Hewitt, C. N., Karl, T., Laffineur, Q., Langford, B., A. McKinney, K., Misztal, P., Potosnak, M., Rinne, J., Pressley, S., Schoon, N., and Serça, D.: Photosynthesis-dependent isoprene emission from leaf to planet in a global carbonchemistry-climate model, Atmos. Chem. Phys., 13, 1024310269, https://doi.org/10.5194/acp-13-10243-2013, 2013.

Ülker, E. D., Tavşanoğlu, Ç., and Perktaş, U.: Ecological niche modelling of pedunculate oak (Quercus robur) supports the "expansion-contraction" model of Pleistocene biogeography, Biol. J. Linn. Soc., 123, 338-347, https://doi.org/10.1093/biolinnean/blx154, 2018.

Van Hees, A. F. M.: Growth and morphology of pedunculate oak (Quercus robur L.) and beech (Fagus sylvatica L.) seedlings in relation to shading and drought, Ann. Sci. Forest., 54, 9-18, https://doi.org/10.1051/forest:19970102, 1997.

Velikova, V., Tsonev, T., Pinelli, P., Alessio, G. A., and Loreto, F.: Localized ozone fumigation system for studying ozone effects on photosynthesis, respiration, electron transport rate and isoprene emission in field-grown Mediterranean oak species, Tree Physiol., 25, 1523-1532, https://doi.org/10.1093/treephys/25.12.1523, 2005.

Velikova, V., Sharkey, T. D., and Loreto, F.: Stabilization of thylakoid membranes in isoprene-emitting plants reduces formation of reactive oxygen species, Plant Signaling and Behavior, 7, 139141, https://doi.org/10.4161/psb.7.1.18521, 2012.

Vitale, M., Salvatori, E., Loreto, F., Fares, S., and Manes, F.: Physiological responses of Quercus ilex leaves to water stress and acute ozone exposure under controlled conditions, Water Air Soil Poll., 189, 113-125, https://doi.org/10.1007/s11270-007-9560-4, 2008.

Vogt, T.: Phenylpropanoid biosynthesis, Mol. Plant, 3, 2-20, https://doi.org/10.1093/mp/ssp106, 2010.

Volz, A. and Kley, D.: Evaluation of the Montsouris series of ozone measurements made in the 19th-century, Nature, 332, 240-242, https://doi.org/10.1038/332240a0, 1988.

Wenda-Piesik, A.: Volatile organic compound emissions by winter wheat plants (Triticum aestivum L.) under Fusarium spp, infestation and various abiotic conditions, Pol. J. Environ. Stud., 20, 1335-1342, 2011.

Wildermuth, M. C. and Fall, R.: Light-dependent isoprene emission, Characterization of a thylakoid-bound isoprene synthase 
in Salix discolorchloroplasts, Plant Physiol., 112, 171-182, https://doi.org/10.1104/pp.112.1.171, 1996.

Wildermuth, M. C. and Fall, R.: Biochemical characterization of stromal and thylakoid-bound isoforms of isoprene synthase in willow leaves, Plant Physiol., 116, 1111-1123, https://doi.org/10.1104/pp.116.3.1111, 1998 .

Williams, L. E. and Araujo, F. J.: Correlations among predawn leaf, midday leaf, and midday stem water potential and their correlations with other measures of soil and plant water status in Vitis vinifera, J. Am. Soc. Hortic. Sci., 127, 448-454, https://doi.org/10.21273/JASHS.127.3.448, 2002.

Wittig, V. E., Ainsworth, E. A., and Long, S. P.: To what extent do current and projected increases in surface ozone affect photosynthesis and stomatal conductance of trees? A metaanalytic review of the last 3 decades of experiments, Plant Cell Environ., 30, 1150-1162, https://doi.org/10.1111/j.13653040.2007.01717.x, 2007.

Worthington Biochemical Corporation: The Worthington Manual, Freehold, New York, p. 1943, 1972.
Wootton-Beard, P. C., Moran, A., and Ryan, L.: Stability of the total antioxidant capacity and total polyphenol content of 23 commercially available vegetable juices before and after in vitro digestion measured by FRAP, DPPH, ABTS and Folin-Ciocalteu methods, Food Res. Int., 44, 217-224, https://doi.org/10.1016/j.foodres.2010.10.033, 2011.

Yener, S., Sánchez-López, J. A., Granitto, P. M., Cappellin, L., Märk, T. D., Zimmermann, R., and Biasioli, F.: Rapid and direct volatile compound profiling of black and green teas (Camellia sinensis) from different countries with PTR-ToF-MS, Talanta, 152, 45-53, https://doi.org/10.1016/j.talanta.2016.01.050, 2016.

Yuan, J. S., Himanen, S. J., Holopainen, J. K., Chen, F., and Stewart, C. N.: Smelling global climate change: mitigation of function for plant volatile organic compounds, Trends Ecol. Evol., 24, 323331, https://doi.org/10.1016/j.tree.2009.01.012, 2009.

Yuan, X., Calatayud, V., Gao, F., Fares, S., Paoletti, E., Tian, Y., and Feng, Z.: Interaction of drought and ozone exposure on isoprene emission from extensively cultivated poplar, Plant Cell Environ., 39, 2276-2287, https://doi.org/10.1111/pce.12798, 2016. 